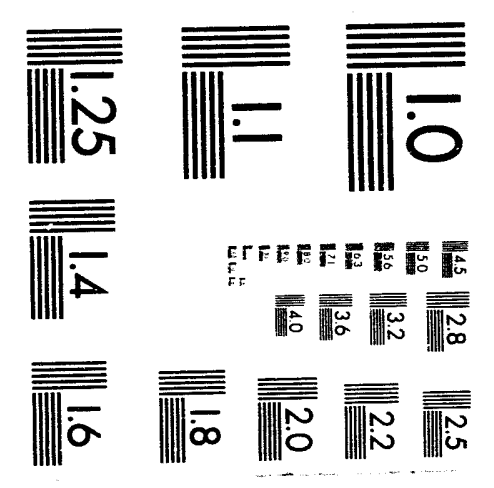



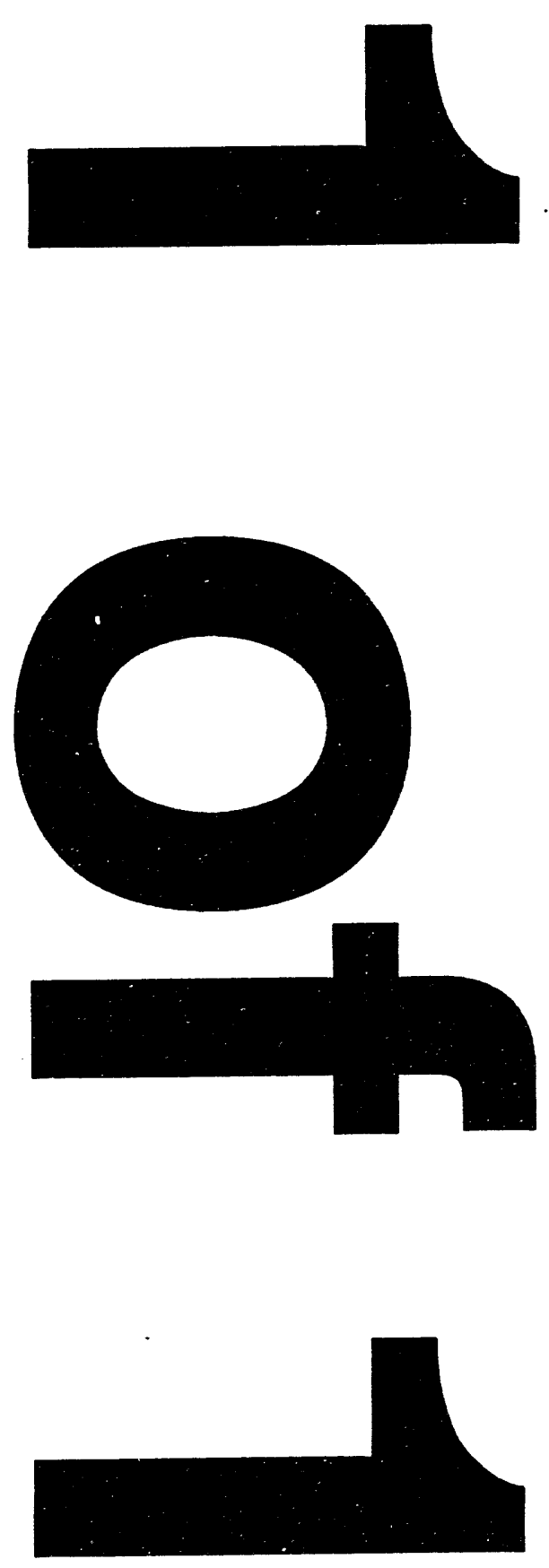


\section{GEOHYDROLOGIC STUDY OF THE MICHIGAN BASIN FOR THE APPLICABILITY OF JACK W. MCINTYRE'S PATENTED PROCESS FOR SIMULTANEOUS GAS RECOVERY AND WATER DISPOSAL IN PRODUCTION WELLS}

By
Steven Maryn

March 1994

\section{DISCLAIMER}

This report was prepared as an account of work sponsored by an agency of the United States Government. Neither the United States Government nor any agency thereof, nor any of their employees, makes any warranty, express or implied, or assumes any legal liability or responsibility for the accuracy, completeness, or usefulness of any information, apparatus, product, or bility for the accuracy, completeness, or usefulness of any informat not infringe privately owned rights. Reference herein to any specific commercial product, process, or service by trade name, trademark, manufacturer, or otherwise does not necessarily constitute or imply its endorsement, recommendation, or favoring by the United States Government or any agency thereof. The views and opinions of authors expressed herein do not necessarily state or reflect those of the United States Government or any agency thereof.

Work Performed Under Jack McIntyre/DOE Contract No. DE-FG46-92R699202

For

Jack W. McIntyre

Fort Stockton, Texas

And

U.S. Department of Energy

Office of Scientific and Technical Information (OSTI)

Oak Ridge, Tennessee

By

Geraghty \& Miller, Inc.

Midland, Texas

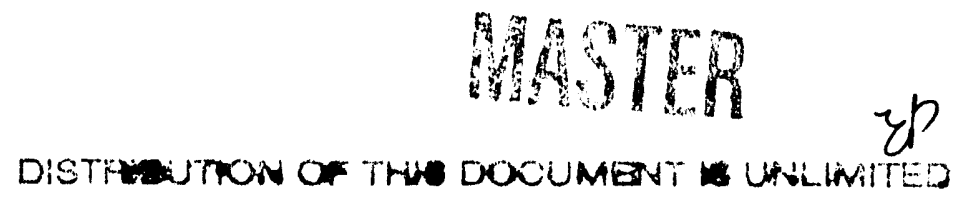




\section{CONTENTS}

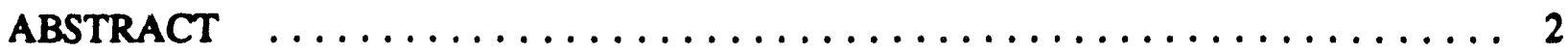

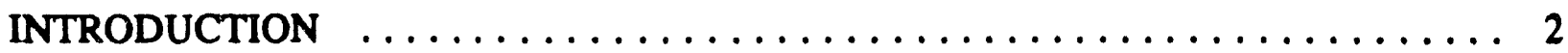

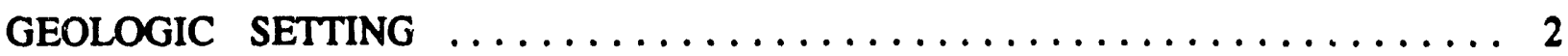

STRUCTURE AND STRATIGRAPHY $\ldots \ldots \ldots \ldots \ldots \ldots \ldots \ldots \ldots \ldots, 4$

STRUCTURE $\ldots \ldots \ldots \ldots \ldots \ldots \ldots \ldots \ldots \ldots \ldots \ldots \ldots \ldots \ldots$

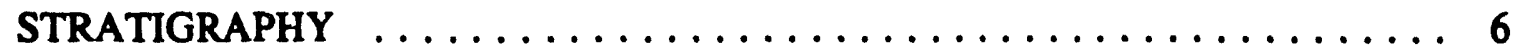

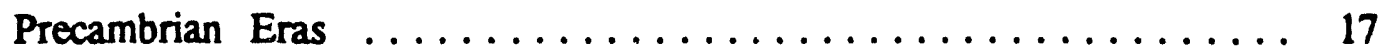

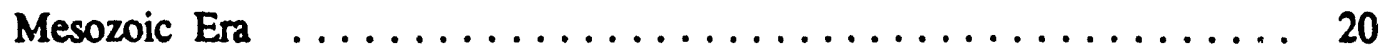

HYDROCARBON OCCURRENCE $\ldots \ldots \ldots \ldots \ldots \ldots \ldots \ldots \ldots, 20$

Coal and Coal-Bed Methane $\ldots \ldots \ldots \ldots \ldots \ldots \ldots \ldots, 20$

Oil and Gas ........................... 21

DEVONIAN SHALE GAS OCCURRENCE, CHARACTERISTICS AND

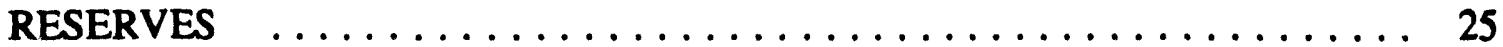

SHALE GAS OCCURRENCE AND CHARACTERISTICS $\ldots \ldots \ldots \ldots 25$

Antrim Shale Gas Generation $\ldots \ldots \ldots \ldots \ldots \ldots \ldots \ldots \ldots$

Porosity and Permeability of the Antrim Shale ........... 27

Antrim Shale Gas and Water Production ............... 27

SHALE GAS RESERVES $\ldots \ldots \ldots \ldots \ldots \ldots \ldots \ldots \ldots \ldots \ldots 28$

Antrim Shale-Estimated $G a s$ in Place $\ldots \ldots \ldots \ldots \ldots \ldots \ldots, 28$

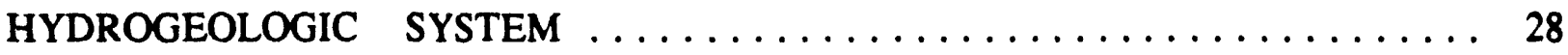

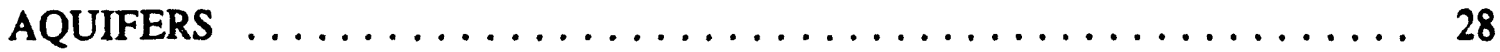

Glacial Drift Aquifer System $\ldots \ldots \ldots \ldots \ldots \ldots \ldots \ldots \ldots \ldots 28$

Bedrock Aquifers $\ldots \ldots \ldots \ldots \ldots \ldots \ldots \ldots \ldots \ldots \ldots \ldots \ldots \ldots, 29$

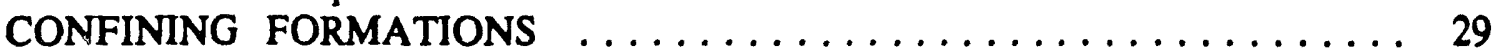

GROUNDWATER QUALITY $\ldots \ldots \ldots \ldots \ldots \ldots \ldots \ldots \ldots \ldots \ldots$

UNDERGROUND INJECTION $\ldots \ldots \ldots \ldots \ldots \ldots \ldots \ldots \ldots \ldots, 32$

Formations Accepting Disposal of Produced Water ......... 32

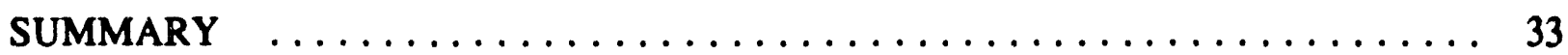

ACKNOWLEDGEMENT $\ldots \ldots \ldots \ldots \ldots \ldots \ldots \ldots \ldots \ldots \ldots \ldots \ldots \ldots$

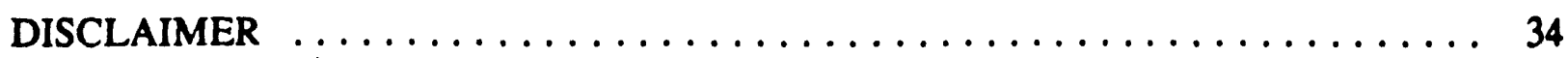

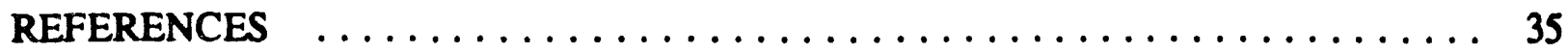




\title{
GEOHYDROLOGIC STUDY OF THE MICHIGAN BASIN FOR THE APPLICABILITY \\ OF JACK W. MCINTYRE'S PATENTED PROCESS FOR SIMULTANEOUS GAS RECOVERY AND WATER DISPOSAL IN PRODUCTION WELLS
}

\begin{abstract}
Geraghty \& Miller, Inc. of Midland, Texas conducted a geohydrologic study of the Michigan Basin to evaluate the applicability of Jack McIntyre's patented process for gas recovery and water disposal in production wells. A review of available publications was conducted to identify, 1) natural gas reservoirs which generate large quantities of gas and water, and 2) underground injection zones for produced water. Research efforts were focused on unconventional natural gas formations.

The Antrim Shale is a Devonian gas shale which produces gas and large quantities of water. Total 1992 production from 2,626 wells was 74,209,916 Mcf of gas and 25,795,334 bbl of water. The Middle Devonian Dundee Limestone is a major injection zone for produced water. "Waterless completion" wells have been completed in the Antrim Shale for gas recovery and in the Dundee Limestone for water disposal. Jack McIntyre's patented process has potential application for the recovery of gas from the Antrim Shale and simultaneous injection of produced water into the Dundee Limestone.
\end{abstract}

\section{INTRODUCTION}

A process patented by Jack W. McIntyre has potential economic and environmental advantages over conventional methods of surface treatment and disposal of produced water from gas wells. The process was tested in the Michigan Basin. The process enables a gas well to be used for both production and water disposal. During production, formation fluids enter the wellbore and gas rises to the surface while water moves down into the disposal zone either by gravity or mechanical pumping. This method allows separation of gas and simultaneous disposal of the formation water without the economic cost and environmental liability associated with bringing the water to the surface. A description and discussion of 
Jack W. McIntyre's gas recovery/water disposal process (US Patent No. 4,766,957) is summarized in the compendium of the seven basins studied under this contract.

The objective of this investigation was to identify the geologic and hydrologic parameters associated with the production of unconventional natural gas resources in the Michigan Basin and to evaluate potential applicability of Jack McIntyre's patented process. The investigation was conducted by reviewing available publications and literature for information about stratigraphy, structure, hydrocarbon production and hydrologic conditions. No field acquisition of data was performed for this investigation by Geraghty \& Miller, Inc.. No testing or evaluation of the effectiveness of Jack McIntyre's gas recovery/water disposal process is presented.

\section{GEOLOGIC SETTING}

The Michigan Basin is an interior cratonic basin located in the Great Lakes region of the United States and Canada. The major portion of the circular sedimentary basin is located in the lower peninsula of Michigan. The lower peninsula is in the Central Lowland physiographic province (Figure 1). The Superior Uplands physiographic province borders the northern perimeter of the Michigan Basin.

Topography of the Central Lowlands consists of gently rolling to flat lowlands. Elevations range from about 180 to 1600 feet above sea level. Primary surface drainage is to Lake Superior, Lake Huron and Lake Erie. Low-lying glaciated terrain is filled with many. lakes, marshes and bogs. 


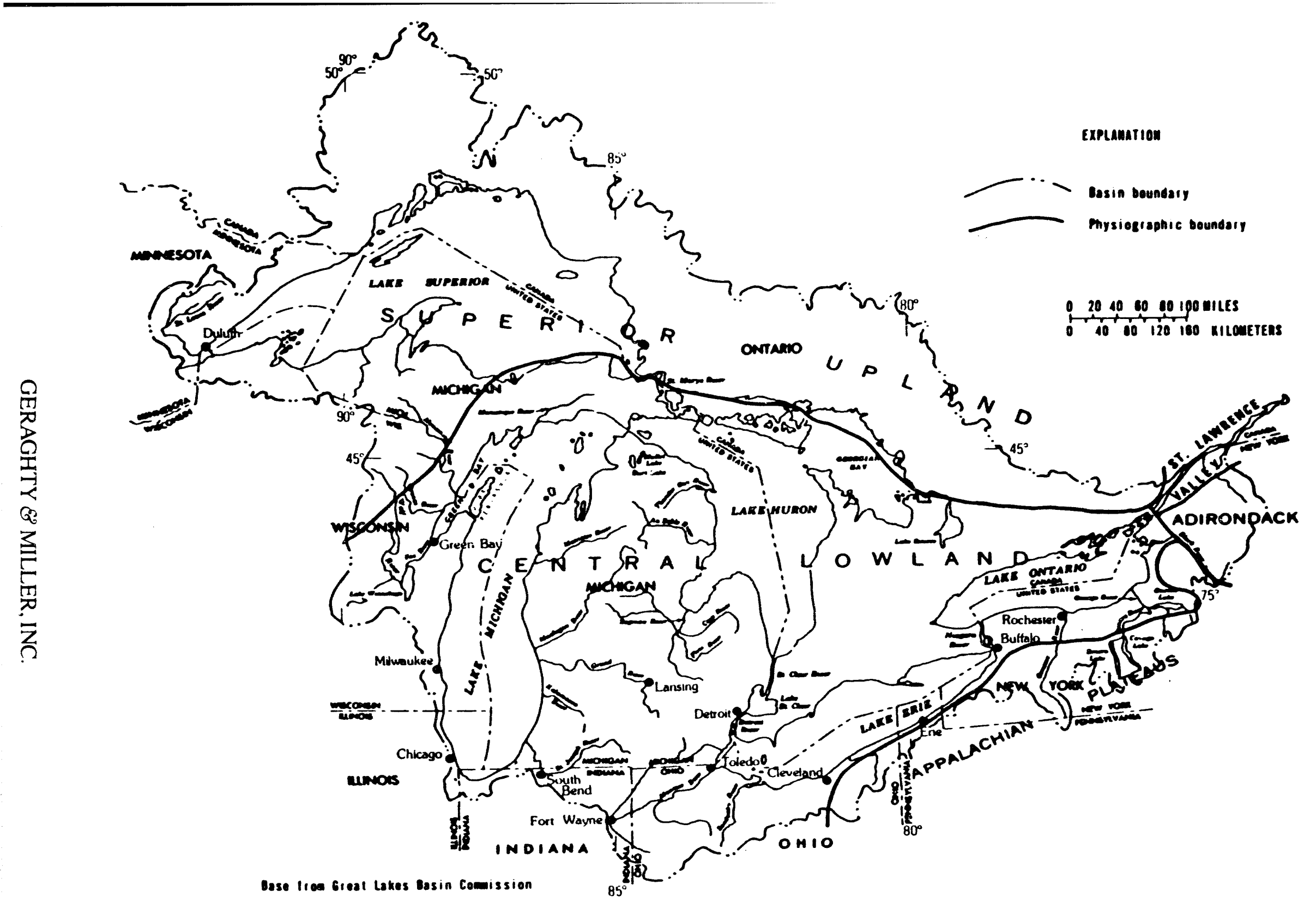

Figure 1. Physiographic Provinces of the Great Lakes Region (from Weist, 1978). 


\section{STRUCTURE AND STRATIGRAPHY}

\section{STRUCTURE}

The Michigan basin is a circular-shaped bowl with a 16,000 foot accumulation of predominantly Paleozoic rocks (sandstones, marine carbonates, evaporites and shales) resting on Precambrian crystalline and sedimentary basement. The basin is centrally located in the lower peninsula and measures 80,000 square miles in area. Outcrops and subcrops are concentric and progress from older formations at the basin perimeter to younger formations towards the basin center (Catacosinos and others, 1990).

The outer portions of the basin extend into parts of Wisconsin, Illinois, Indiana, Ohio, Ontario, Canada and the Upper peninsula of Michigan (Catacosinos and others, 1990). Regional structures bounding the Michigan Basin are the Kankakee Arch (southwest), Wisconsin Dome and Arch(west), the Canadian Shield (north), the Algonquin Axis (southeast) and the Findlay Arch (south-southeast) (Figure 2).

Faults and fractures trend northwest and southwest. The Howell Anticline, located in the southeast corner of the basin, trends northwest. Some oil and gas field patterns also trend in the same directions (Newcombe, 1933; Catacosinos and others, 1990). A buried rift of Precambrian age has been interpreted from a gravity anomaly (Hinze et al., 1975; Fowler and Kuenzi, 1978;). The rift is associated with over 5,000 feet of Precambrian red clastics and is bounded by crystalline Precambrian rock (Lilitenthal, 1978). The rift trends generally northwest-southeast through the center of the basin (Fowler and Kuenzi, 1978; Catacosinos and others, 1990). According to Lilienthal (1978), the Michigan Basin began forming in Precambrian time and continued downwarping through the Paleozoic. Silurian-Salina and Devonian-Detroit River times are believed to be major periods of downwarping. 


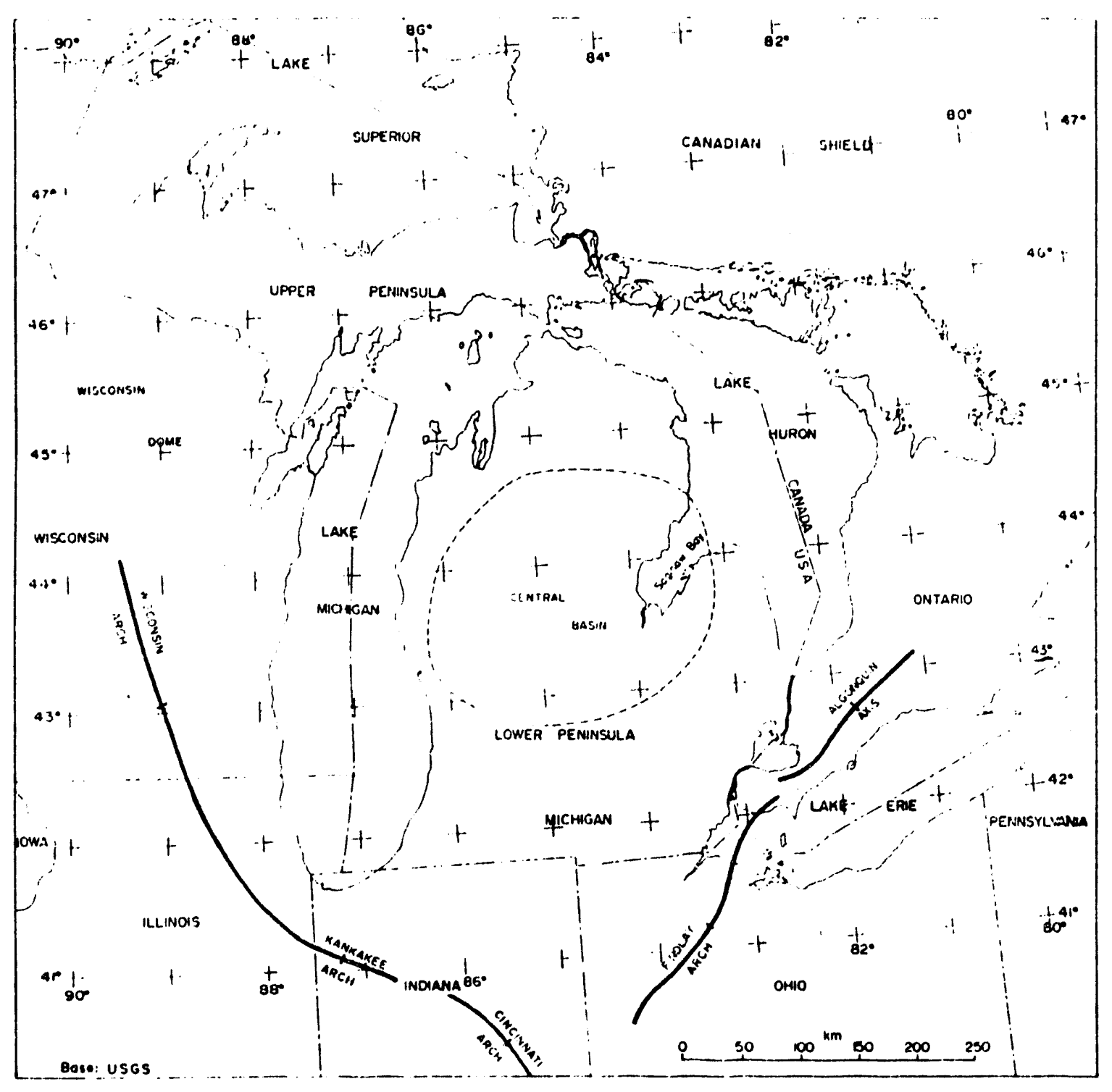

Figure 2. Regional Structure Map (from Vugrinovich, 1986). 


\section{STRATIGRAPHY}

The stratigraphic nomenclature used for this report is from the Stratigraphic Succession in Michigan, Chart 1, 1964 published by the Michigan Department of Natural Resources (Figure 3) and nomenclature used by Lilienthal, 1978, Stratigraphic CrossSections of the Michigan Basin, Report of Investigation 19, MI DNR, and Briggs, (1968). The Geologic Bedrock Map of Michigan (Kelley,1968) illustrates the concentric bands of subcrop/outcrop of the basin and includes a generalized cross-section (Figure 4). Figure 5 is an index map for stratigraphic cross-sections from Lilienthal, 1978, and Figures 6 through 12 are the selected cross-sections (From Lilienthal, 1978). The figures selected show the Precambrian through Jurassic stratigraphy from central Michigan and north through Otsego County. Otsego County is the predominant location where Antrim Shale gas activity is occurring. The cross-sections centered around the deepest well drilled in Michigan, (the McClure Oil Company - Sparks, Eckelbarger, Whightsil No. 1-8, Gratiot County) which was advanced to a total depth of 17,466 feet. The logs depict porosity, density, conductivity and lithology of the sedimentary strata. Abundant porosity zones were noted in the Traverse Limestone, the Dundee Limestone and the Lucas Formation of the Devonian System (Lilienthal, 1978).

Time-stratigraphic strata in the Michigan Basin, in ascending order, are the Precambrian basement rocks, the Paleozoic rocks composed of the Cambrian, Ordovician, Silurian, Devonian, Mississippian, and Pennsylvanian Systems, the Mesozoic rocks (Jurassic System) and Cenozoic rocks of Quaternary age.

The stratigraphic section in the Michigan Basin is composed of six basic lithologic groups:

- Precambrian granites, gneiss, metasedimentary clastics and metavolcanic.

- Cambrian sandstones, sandy dolomites, dolomites and shales. 


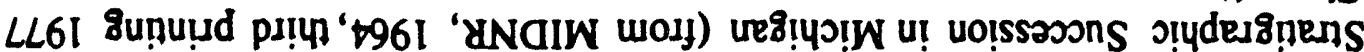 \\ ๔ อมกรి!}
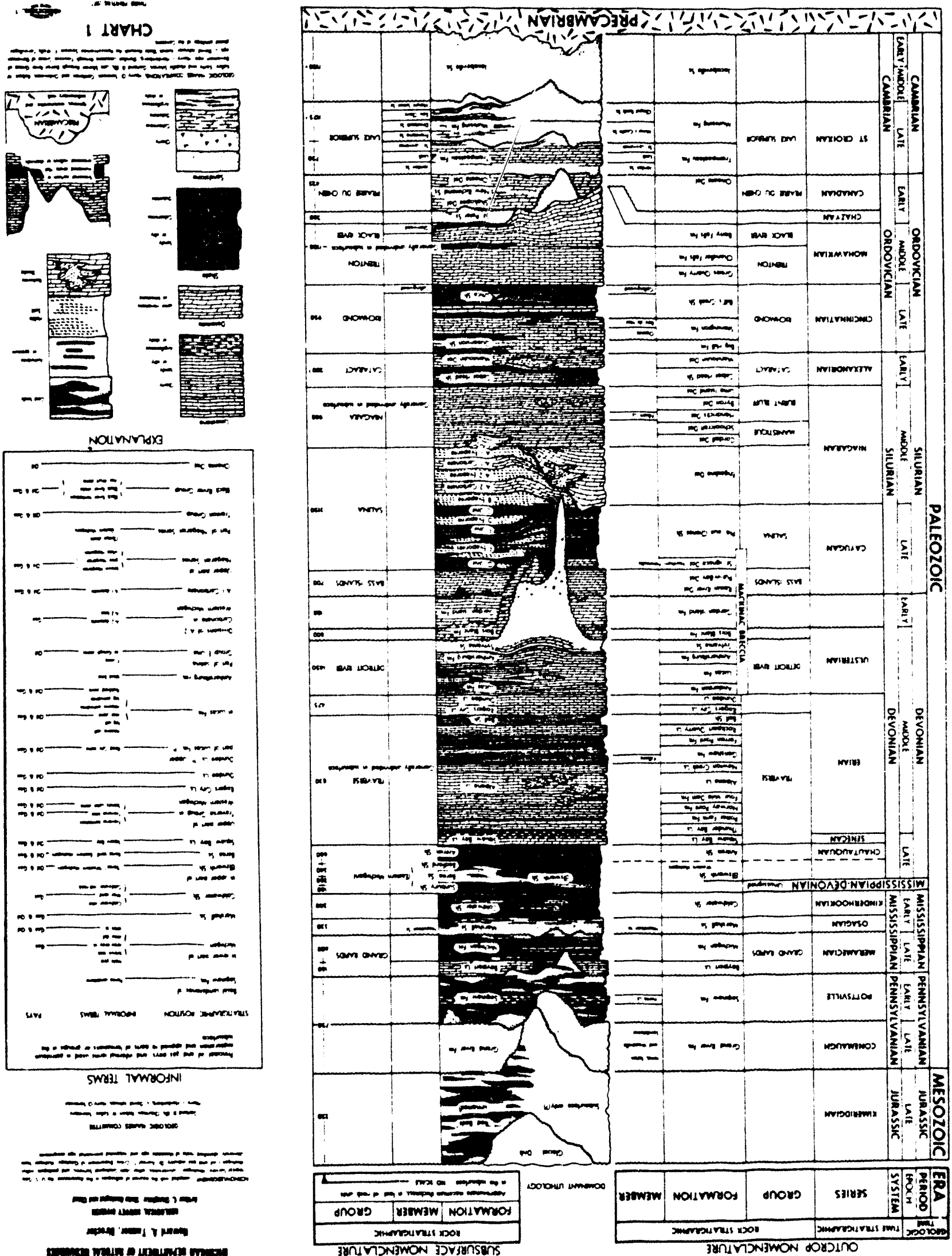

$L$

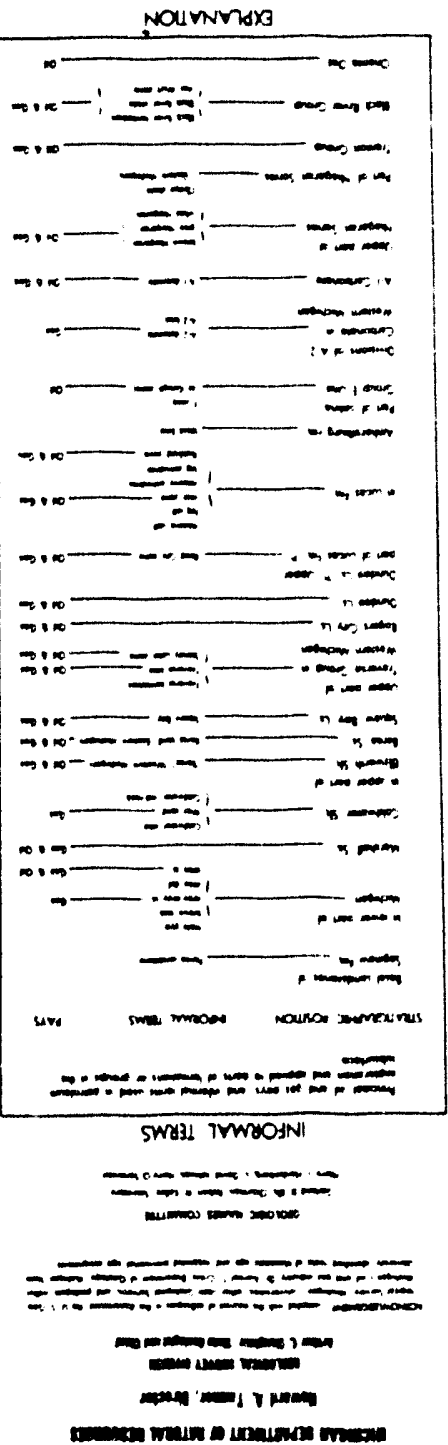

(n)

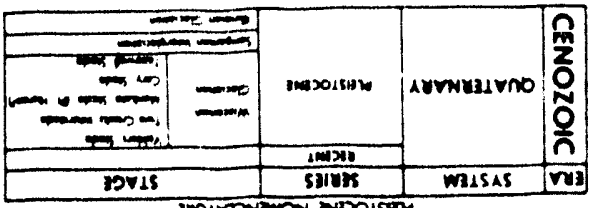




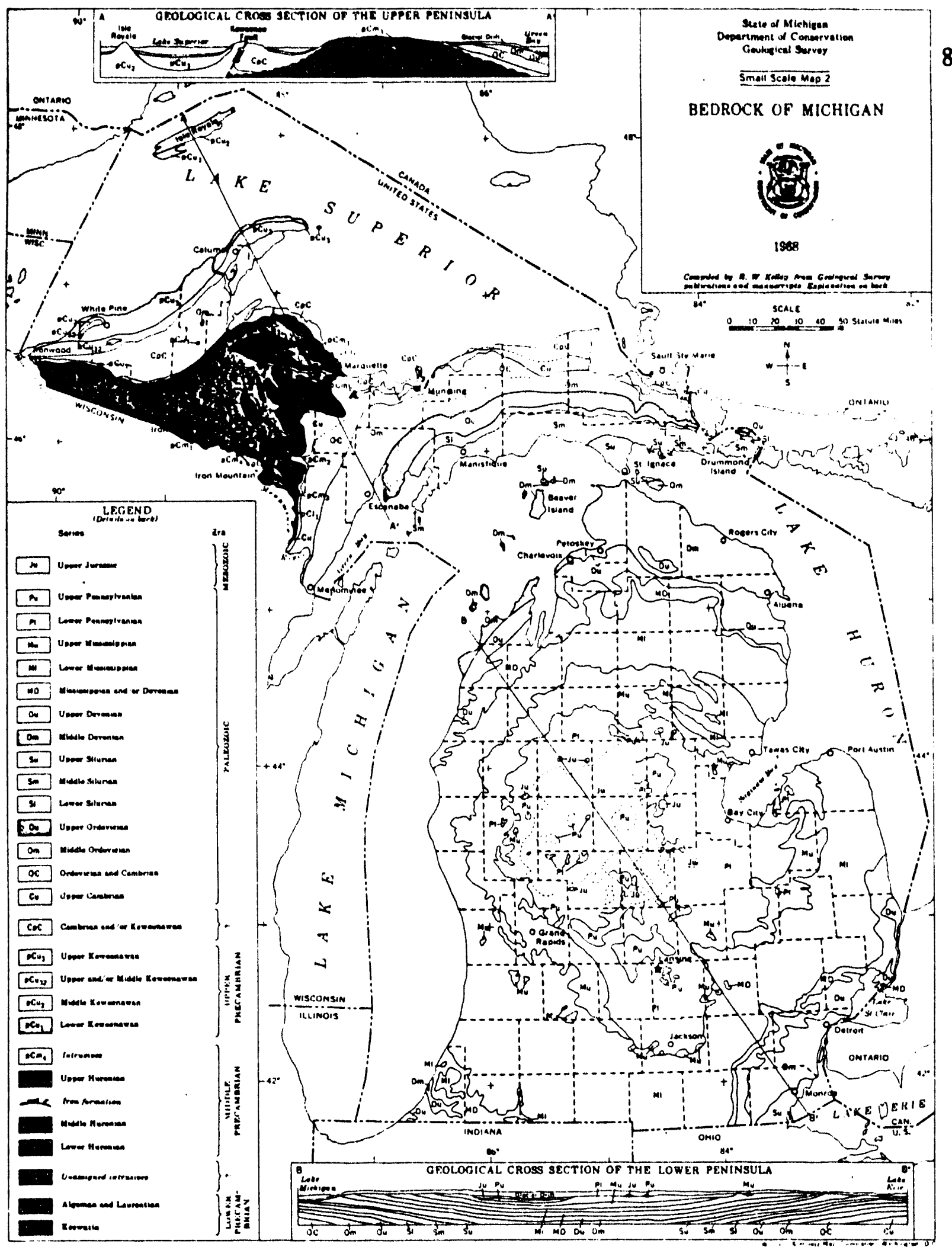

Figure 4. Geologic Bedrock Map of Michigan (from MIDNR, 1968, small scale Map 2) 


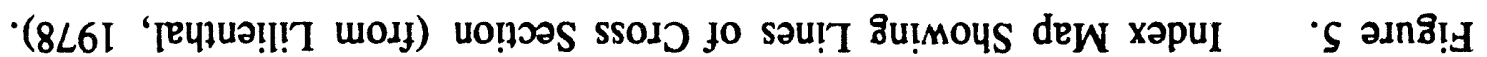

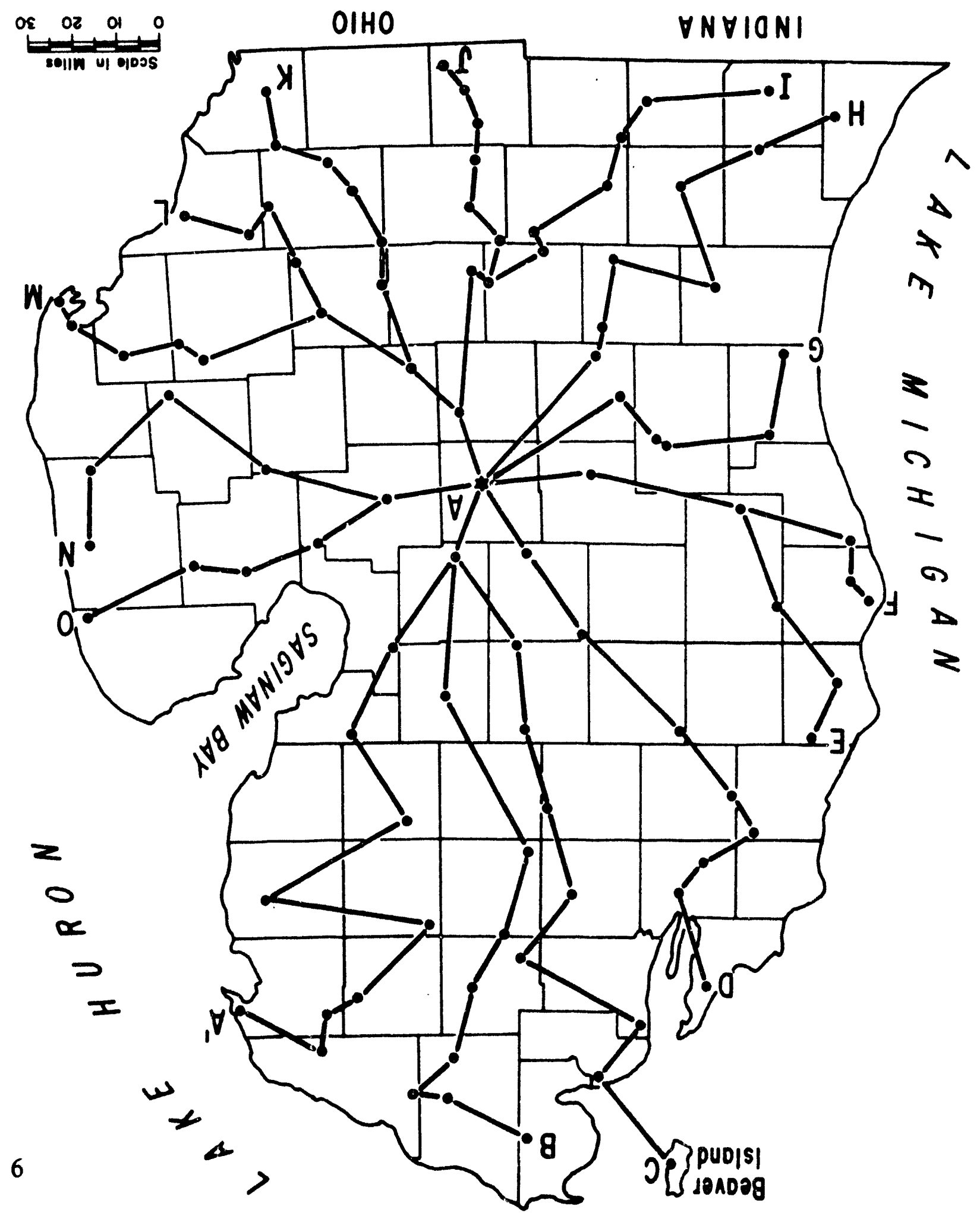



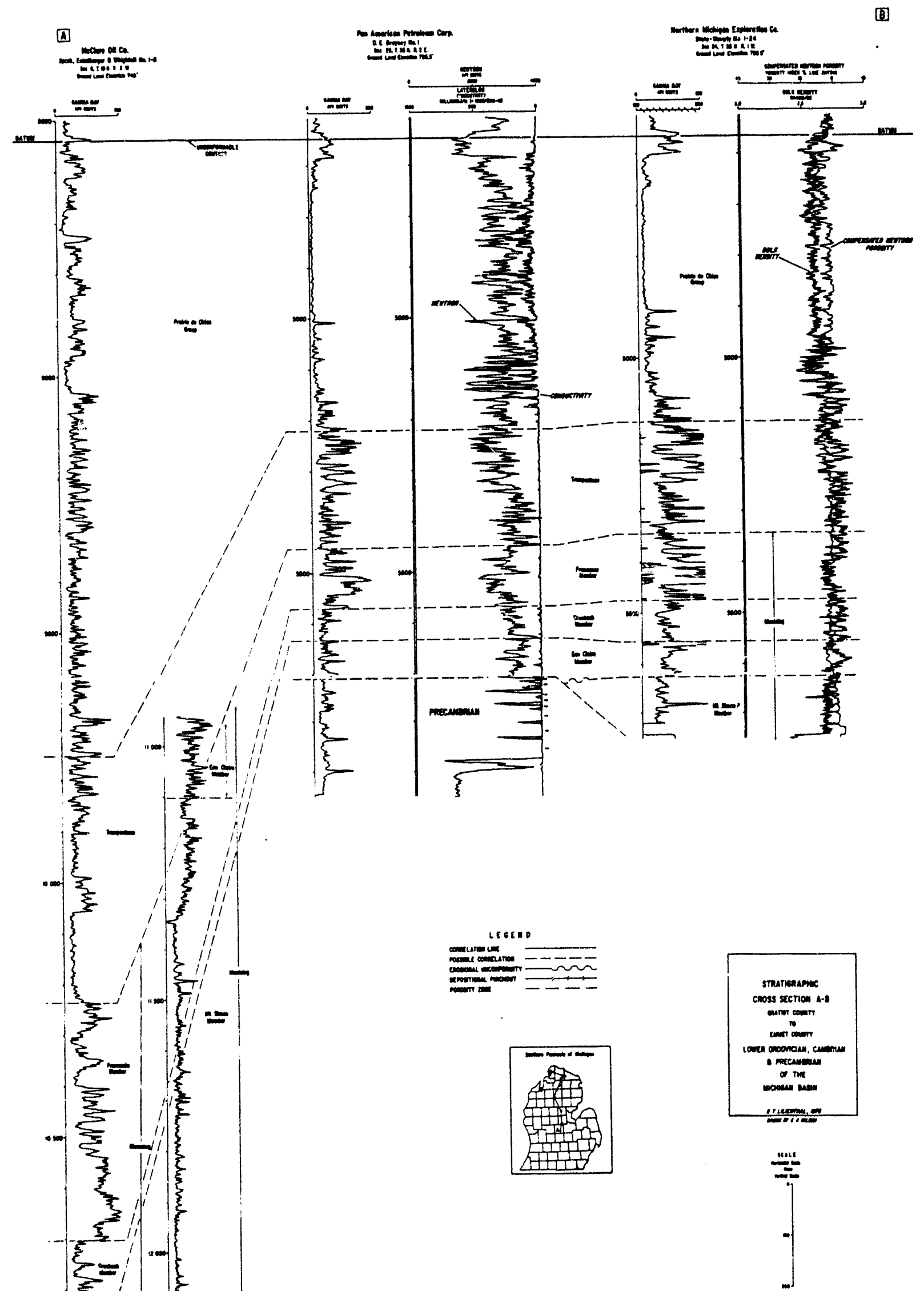

Figure 6. Stratigraphic Cross Section A-B of the Lower Ordovician, Cambrian \& Precambrian of the Michigan Basin (from Lilientha1, 1978). 

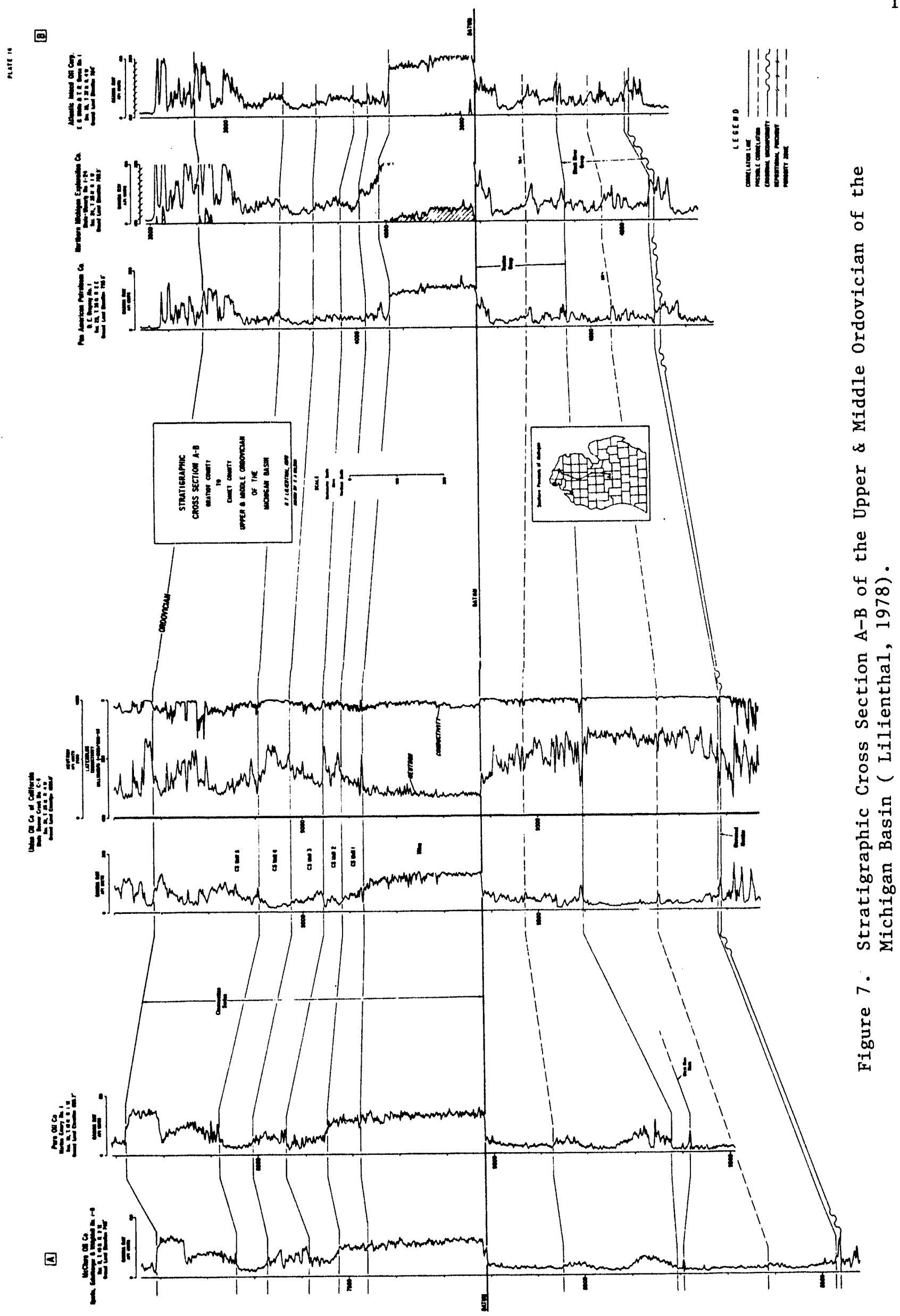

GERAGHTY E⿱乛E MIL.LER, INC. 


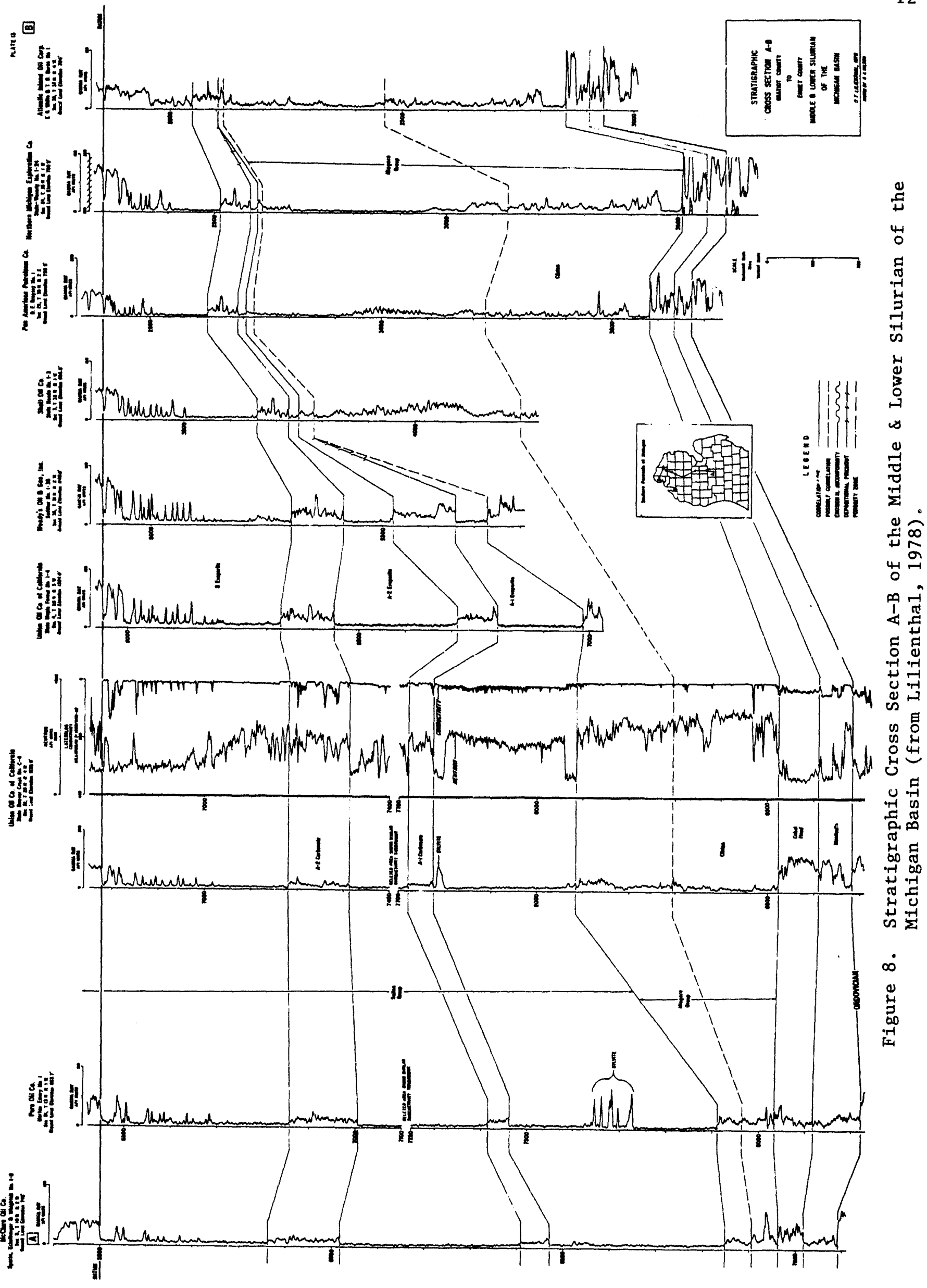




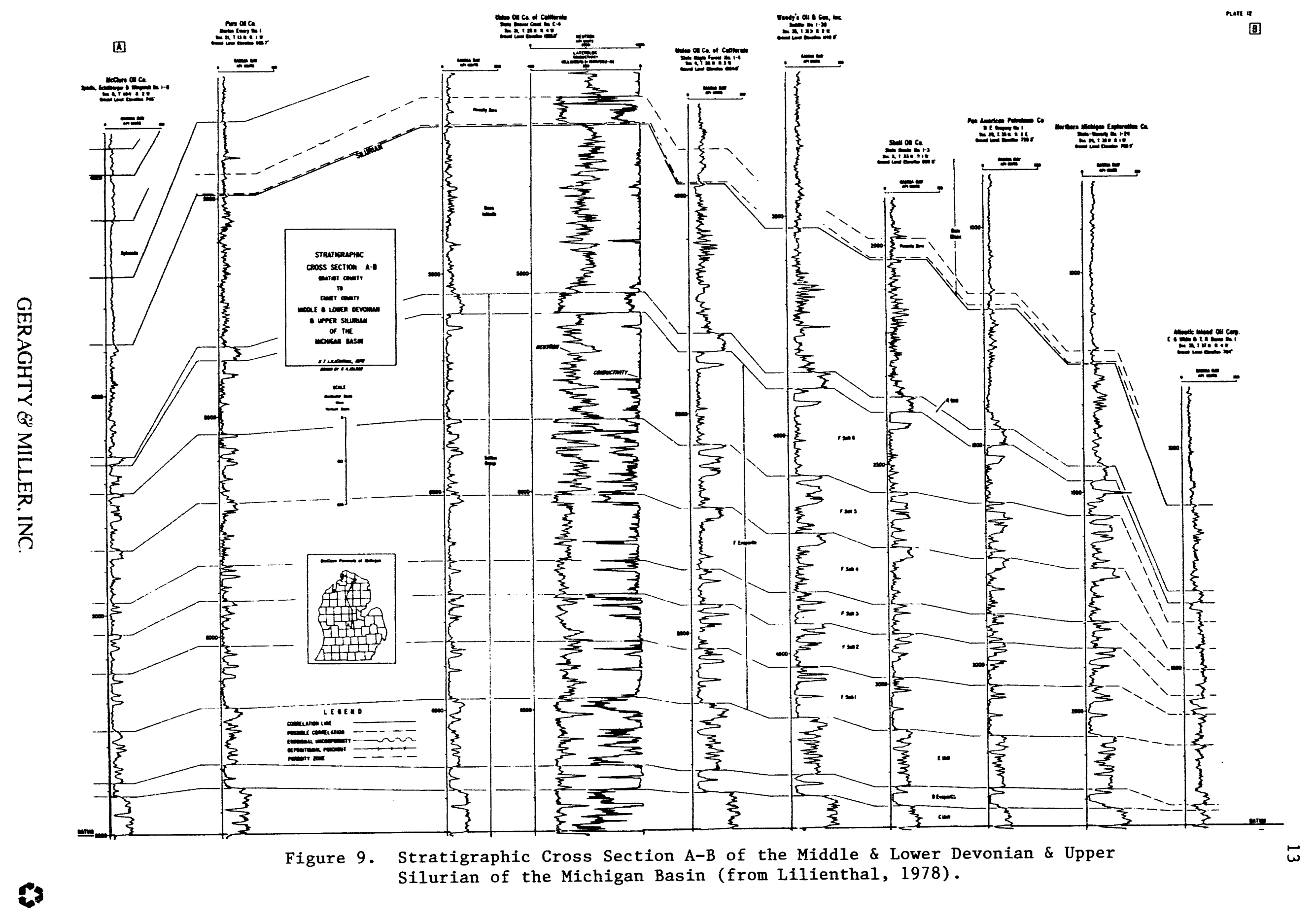




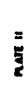
ifi

11

[I]

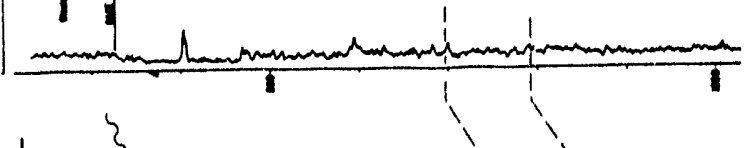
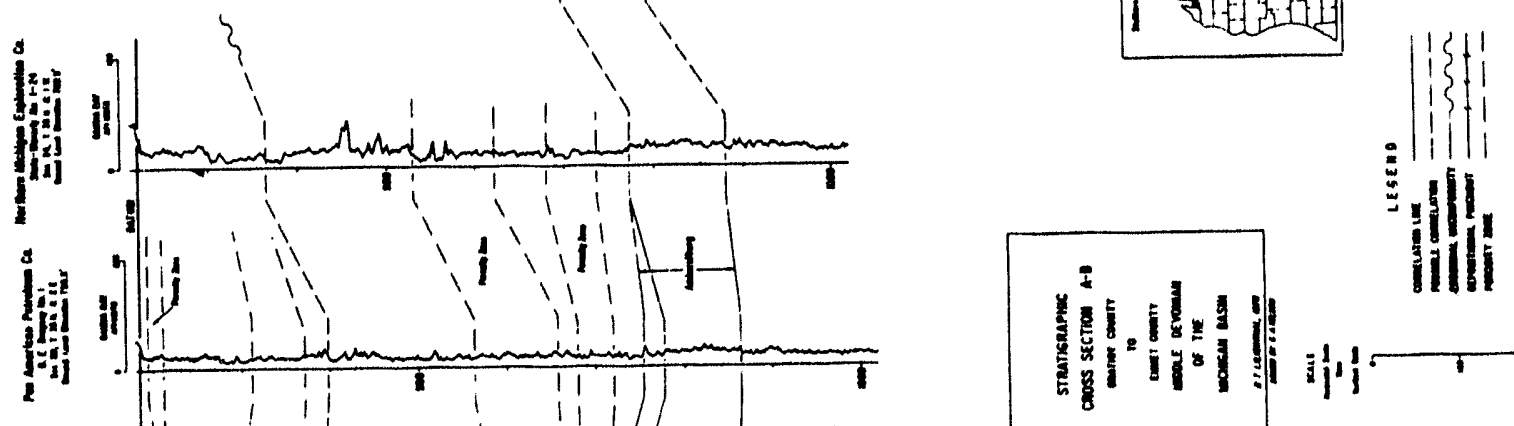

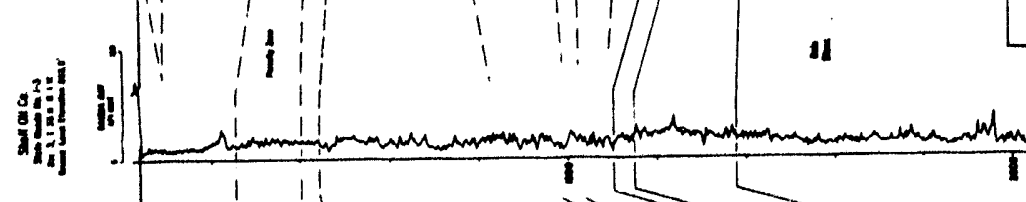

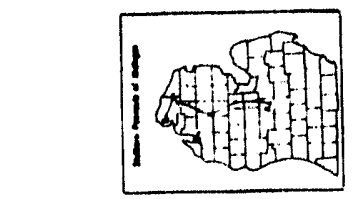

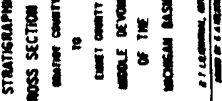

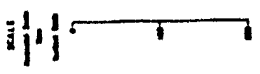

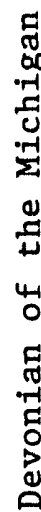

促:

1 1

1

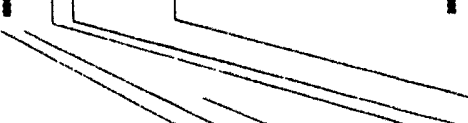

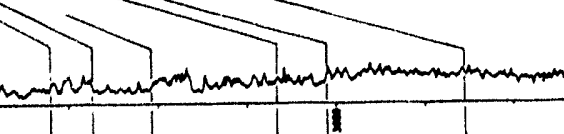

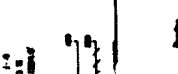

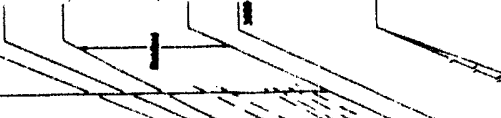

$=-2$

it

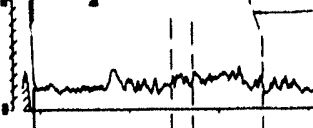

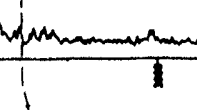

I.

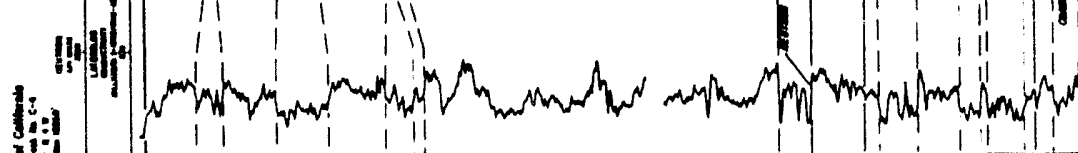

fiil
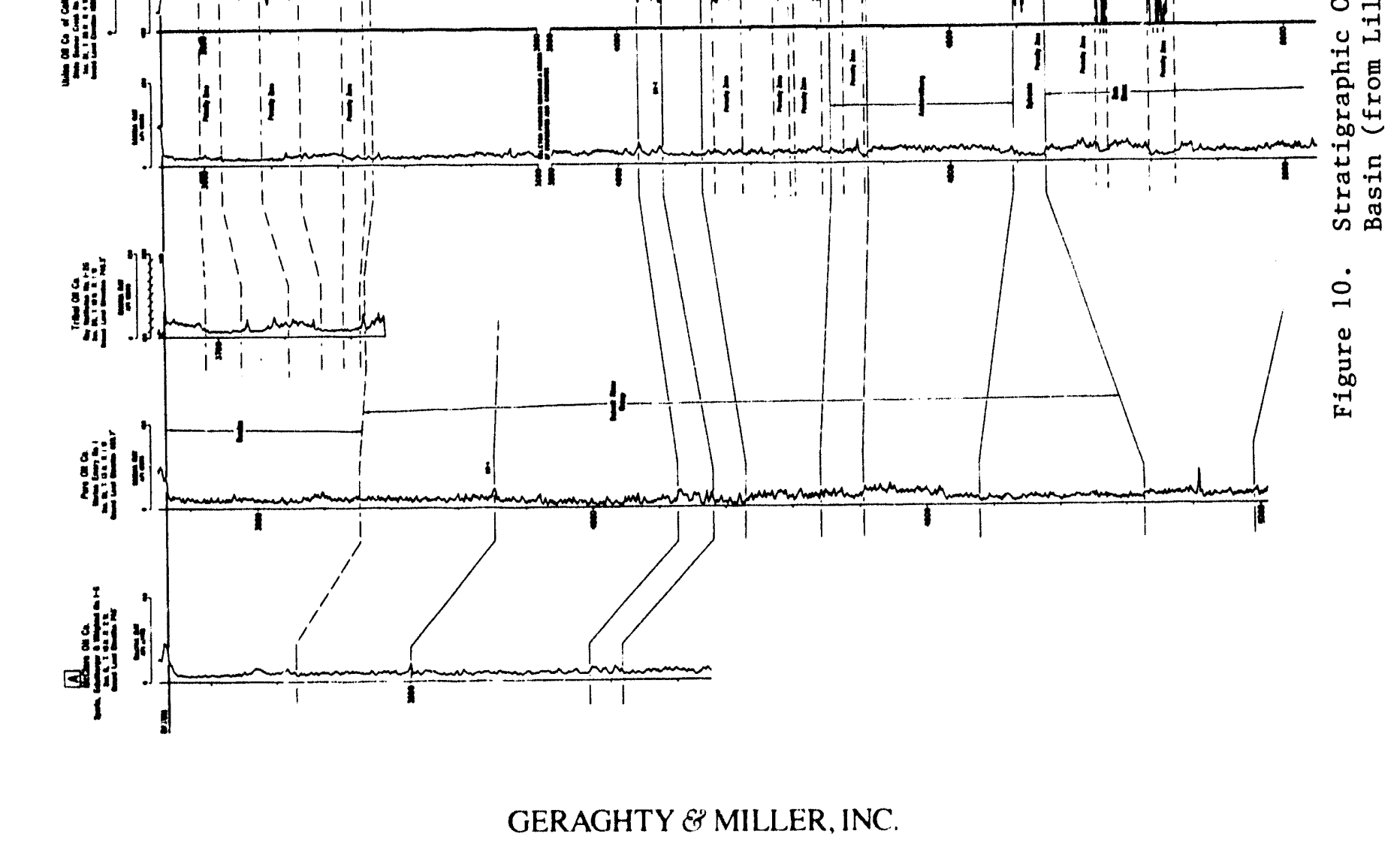

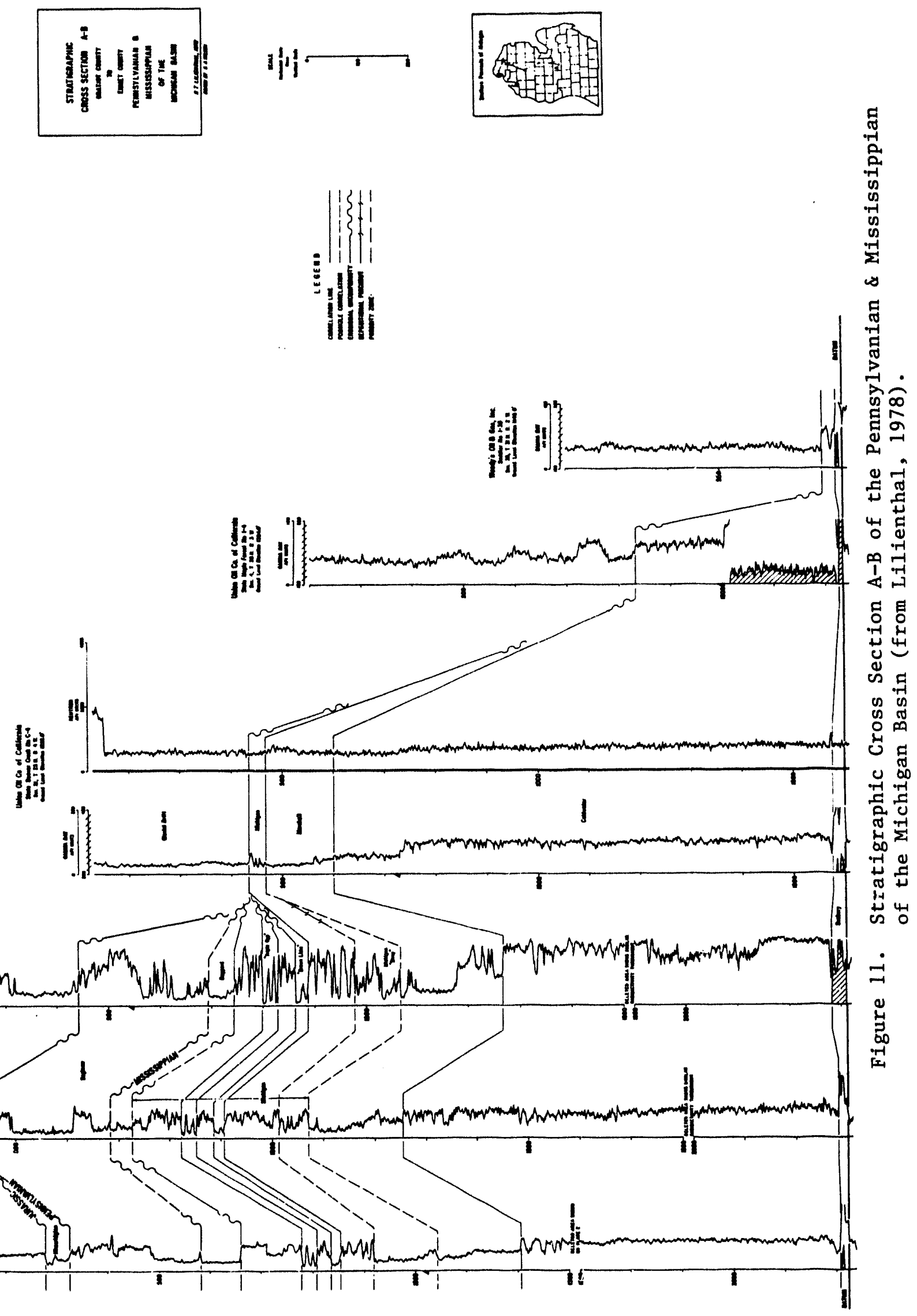


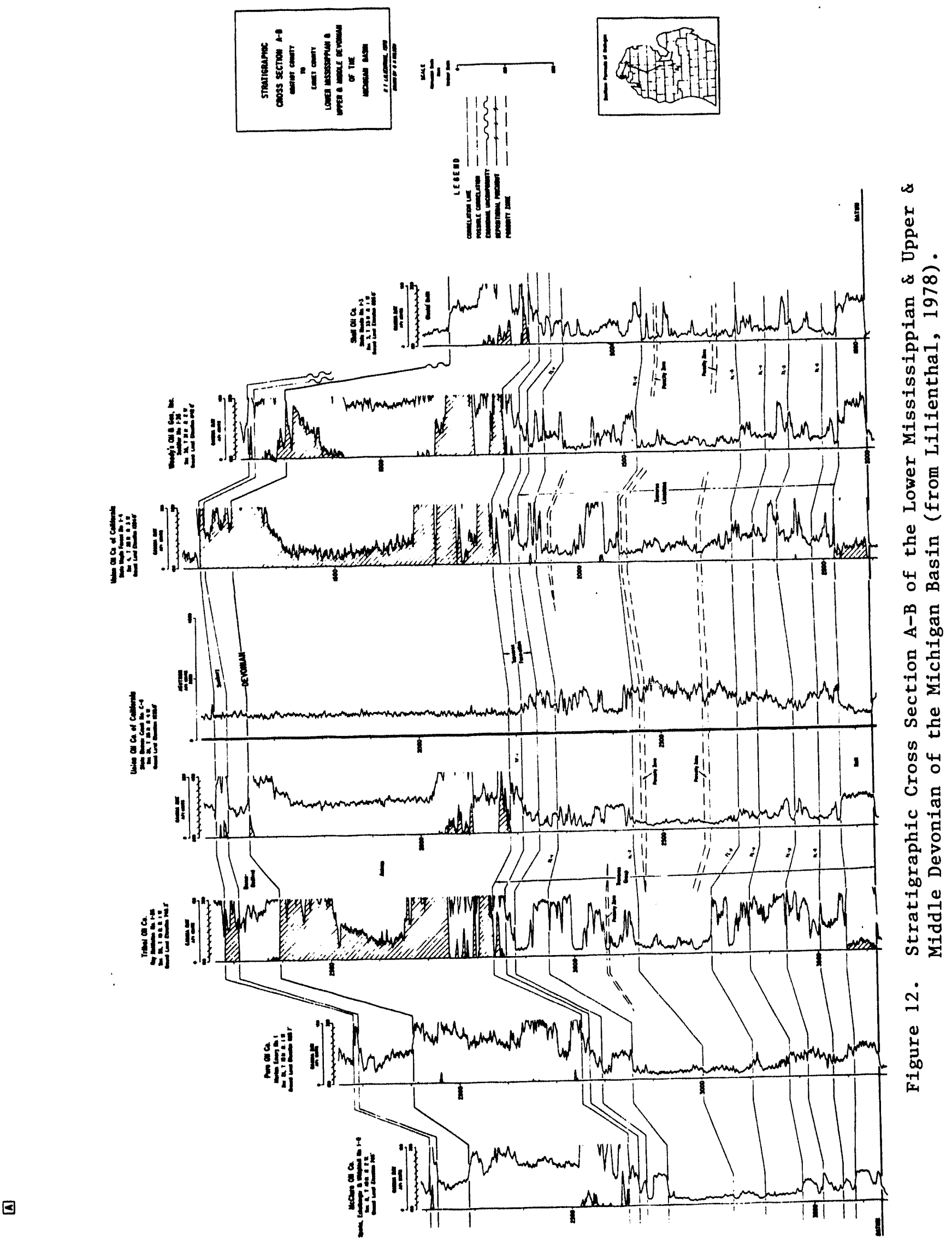


- Ordovician to Middle Devonian carbonates with interbedded evaporites, shaly carbonates, shales and sandstones.

- Late Devonian to Pennsylvanian rocks composed of primarily shale interbedded with sandstone, siltstone and carbonates, and thinly bedded evaporites.

- "Red Beds" of Jurassic Age which lie unconformably on the eroded Pennsylvanian bedrock. The Jurassic "Red Beds" were dissected and eroded during a pre-Pleistocene glacial event.

- Unconsolidated sands, gravels, tills and clays deposited during Pleistocene glacial events (Vugrinovich, 1986).

\section{Precambrian Eras}

Through 1978, 30 test holes have been drilled into the Precambrian basement rocks of the Lower Peninsula and most encountered granitic rocks. By 1984, 42 test holes encountered the Precambrian basement in the Lower Peninsula. Depths to the Precambrian basement ranged from 3,342 to 12,176 feet (Catacosinos and others, 1991). Geophysical surveys suggest mafic rocks are widespread in the Precambrian basement of the Michigan Basin (Hinze and Merritt, 1969; Lilienthal, 1978) Briggs' (1968) generalized columnar section of Michigan showed lavas, conglomerate, iron formations, schist, gneiss and granites as Precambrian rocks. Four major provinces are found in the Lower Penninsula of Michigan. They are the Grenville, Central, Penokean and the rift zone (Hinze and Merritt, 1969). Over 5,000 feet of red beds were encountered beneath the Mt. Simon sandstone during the McClure Oil Company deep test. The red beds are believed to be of late Keweenawan Age (Lilienthal, 1978).

A generalized stratigraphic succession overlying the Precambrian basement with general lithology and maximum general thickness is presented below. 


\section{Cambrian System}

Jacobsville Sandstone - Sandstone $-1100 \mathrm{ft}$.

Lake Superior Group

Munising Formation

Mt. Simon - Sandstone - $1100 \mathrm{ft}$.

Eau Claire - Sandstone, limestone - $100 \mathrm{ft}$.

Dresbach - Sandstone - $\{90 \mathrm{ft}$. $\}$

Franconia - Sandstone - \{included in Dresbach\}

Trempealeau Formation - Dolomite - $750 \mathrm{ft}$.

\section{Ordovician System}

Prairie du Chien Group - Dolomite, sandstone - $400 \mathrm{ft}$.

Oneota Dolomite

New Richmond Sandstone

Shakopee Dolomite

St. Peter Sandstone (Chazyan) - Sandstone - $200 \mathrm{ft}$.

Black River Group - Limestone, dolomite - $500 \mathrm{ft}$.

Trenton Group - Limestone, dolomite - $500 \mathrm{ft}$.

Richmond Group (Richmond-Maysville) - Shale, limestone - $450 \mathrm{ft}$.

Utica Shale - Shale - $500 \mathrm{ft}$.

\section{Silurian System}

Cataract Group - Dolomite, shale - $200 \mathrm{ft}$.

Niagaran Group - (Clinton) - Dolomite, shale - $1000 \mathrm{ft}$

Salina Group - Salt, anhydrite, dolomite $-3150 \mathrm{ft}$.

A-1 Evaporite - Salt

A-1 Carbonate - Dolomite 

A-2 Evaporite - Salt
A-2 Carbonate - Dolomite
B Evaporite - Salt
C Unit - Argillaceous dolomite
D Evaporite ' - Salt
E Unit - Dolomite
F Evaporite - Salt
G Unit - Argillaceous dolomite

Bass Islands Group - Dolo! nite, anhydrite - $700 \mathrm{ft}$.

\section{Devonian System}

Garden Island Formation - Dolomite, shale, sand - $100 \mathrm{ft}$.

Bois Blanc Formation - Dolomite, limestone, chert - $1100 \mathrm{ft}$.

Detroit River Group - Dolomite, anhydrite, salt, sandstone - $1700 \mathrm{ft}$.

Sylvania Sandstone

Amherstburg Formation

Lucas Formation

Dundee Limestone - Limestone - $800 \mathrm{ft}$.

Rogers City Limestone - Limestone \{included in Dundee\}

Traverse Group - Shale, Limestone - $800 \mathrm{ft}$.

Bell Shale

Alpena Limestone

Squaw Bay Limestone

Antrim Shale - Shale, limestone - $600 \mathrm{ft}$.

Ellsworth Shale - Shale - $600 \mathrm{ft}$.

\section{Mississippian System}

Bedford Shale 
Berea Sandstone

Sundbury Shale

Coldwater Shale - Shale, sandstone $-1300 \mathrm{ft}$.

Marshall Sandstone - Sandstone - $350 \mathrm{ft}$.

Grand Rapids Group

Michigan Formation - Shale, gypsum, dolomite - $600 \mathrm{ft}$.

Bayport Limestone - Limestone, dolomite - $150 \mathrm{ft}$.

\section{Pennsylvanian System}

Saginaw Formation - Shale, limestone, coal, sandstone - $550 \mathrm{ft}$.

Grand River Formation - Sandstone - $200 \mathrm{ft}$.

\section{Mesozoic Era}

Jurassic System

"Red Beds" - Sand, clay - $200 \mathrm{ft}$.

\section{Cenozoic Era}

Quaternary System

Glacial Drift - Boulder, clay, gravels - 850 feet

\section{HYDROCARBON OCCURRENCE}

\section{Coal and Coal-Bed Methane}

The Pennsylvanian Saginaw Formation contains coal seams that are thin and laterally discontinuous. Between 1835 and 1949, 46 million short tons of coal were produced in 
Michigan (Cohee et al., 1950; Kalliokoski and Welch, 1977). One estimate of identified reserves of bituminous coal remaining in the Saginaw Formation is 205 million short tons (Averitt, 1974). Most of the coal is at shallow depths of less than 1,000 feet and covered with glacial deposits.

A review of available literature was conducted to determine if any coal-bed methane potential existed in the Saginaw Formation. No data indicating significant coal-bed methane potential was found.

The Michigan Basin was, not identified as a coal-bed methane prospect in the Quarterly Review of Methane From Coal Seams Technology(ICF Resources, Inc., Vol. 7, No. 3, March, 1990).

\section{Oil and Gas}

Oil and gas production occurs in Mississippian to Ordovician-age formations. In the Mississippian formations, hydrocarbon production is primarily in sandstones such as the Stray and Berea. Reservoir/trap consist of a combination of stratigraphic and structural types. The Devonian shales, such as the Antrim, are of the combination stratigraphic/structural type reservoir/trap. Hydrocarbons in Devonian carbonates such as the Traverse and Dundee Limestones, are of the anticlinal reservoir/trap type. Hydrocarbons in Silurian carbonates, such as the Niagaran reefs, are of the stratigraphic reservoir/trap type. Ordovician carbonates have hydrocarbon accumulations in combination stratigraphic and structural reservoir/traps. The Trenton and Black River units are examples of this type. Hydrocarbons found in the Ordovician Glenwood and St. Peter Sandstones are in anticlinal reservoir/traps (Catacosinos and others, 1991).

Production records from the Michigan Department of Natural Resources and Michigan Public Service Commission were reviewed for natural gas formations which produce significant quantities of water and gas. Formations which produce both oil \& gas, 
or gas condensate and water were not considered for potential application of Jack McIntyre's patented process. Upon initial review, two producing intervals were identified for closer evaluation, the Ordovician Prairie Du Chien Group (PDC) and the Antrim Shale.

The PDC produces gas, gas condensate, oil and water, however some wells produce only gas and water. The PDC is stratigraphically the deepest gas producing zone in the Michigan Basin. Production records for the PDC indicate the majority of the gas wells produced little or no water (MI DNR, 1991 AWSUM, 1993). Evaluation of the PDC for potential application of Jack McIntyre's patented process would require a more localized study to identify individual wells which might benefit from application of the technology. The technology may also be of benefit to other specific wells in other fieids. This report focused on a review of general field characteristics for the majority of production wells.

The Antrim Shale produces significant quantities of natural gas and water. Low thermal maturation of the organic rich black shale facies appears to have limited oil potential in the formation. Total Antrim Shale gas and water production for 1992 totaled $74,209,916 \mathrm{Mcf}$ and 25,795,334 bbl, respectively (MSPC Antrim Gas Well Database, 1993) (Table 1).

The Stratigraphic Succession of Michigan Chart 1 shows oil and gas producing zones (Figure 3) except for the Devonian Antrim Shale (the shallow play) and the Ordovician St. Peter Sandstone, the overlying Glenwood Formation and underlying PDC (the deep play "Massive Sand").

Potential prospects in the Cambrian Munising Group includes the Galesville and Franconia formations. Shows were reported in the Galesville Sandstone, the Franconia Formation and the underlying Mt. Simon Sandstone. The Cambrian Mt. Simon Sandstone is a potential hydrocarbon exploration prospect (Catacosinos, 1979; Catacosinos and others, 1991). 
Fietd mane

opematon

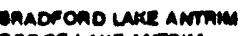

Dooce Lake ANTAM

- 2 ANTMIM PROJECT
TOWEA ANTMIM PROSECT

Aac oI mares

ase 02. Ase oso

ase asA stare

Ase o4. Ase o4a

Ase A3c. Ase 612

Ase 09. Aat ow

ase orC

MMAO \&2. NMAO 13

ICV

AXPOAD PAONeCT

covamnen PnONeCT

QAnOMEA PROJECT

KUAACKI PMOJECT

SCMMAOEA PMOJECT

JA BOTT ANTAIM

CHesten -

MATER ANTMIM

CHCLEY W ANTMIM

CHESTEA W ANTAIM

SOUTH (OTSEOO LAKE)

N. VENMA 27

LEO M AKEY

CMAnLTON 14

maren

STATE-MAYES

VIENMA-CHARLTON

meoenic!

me OEAIC

PAE DEAIC

mAE OEAIC PAOKECT

sases Lake

calukins laxe

compo laxe

EABT MEANT LaKe

emenalo Lake

ancell LAKE

menar UKE

Monicon 1

unte Crupo LaKE

Lowen chle Lake

urtcrell Lake

no uake

month MDOCEN LAKE

OPAL UKE

orsecoo Lake

metoh laxe

mocon miven

nouno LAKE

SOUTH MDOEN UKe

mavense uKes

numo lake

BACLEY EAST
CMESTEA EAST

mares 10

wo DAgS LAKE ANTRIM

macier 17

cresten 12 (FOX)

climana 9

manken 30

Crmalton es - a

CMultion 10 PAOJ1 - 6

cresten 7 orseco 124

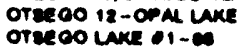
Detra on co... INC
ANTAMA DeVELOPAEWT Throm AMTnum oevelopment ANTrim oevelopuent ANThim eas inc ANTrim eas INC ANTAIM GAS INC ANTMim CAS INC ANTAIM CAS INC ANTmIM OAS INC ANTnim ons INC ANTRIM CAS INC ANTMIM OAS INC ANTTIM OAS INC ANTAIM CAS INC DELTA OL CO.. HC Delta oll co. NNC. DelTA OU CO. INC. oevomin Enenor. inc DONONLN ENEROV. INC DON YOME ENTEAPAISES FPI ANTAIM ONE. INC PPI ANTRIM ONe. INC in ravemale

in raveHAur

Jo INC

LEO M. AREY COMPANY MACK OL COAPOAATION Mack OU COAPOAaTION MACK OU COAPOAATION MACK OH COAPOAATION MEACUAY ExPLOAATION MEACUAY EXPLOAATION MEACUAY EXPLOAATION MEACUAY EXPLOAATION MEACUAY EXPLOMATION MUakeOON OEVLLOPMENT MuxeOON OEVLLOPMENT MuaxeCON DeVLLOPMENT MUAKEOON OEVELOMENT MUSKEOON DEVLLOPMNT MUSKEOON DEVLLOPENT MUSKEOON DEVLOPMENT MUSKEOON DEVLLOPMENT MUSKEOON OEVLLOPMENT MUSKEOON DEVELOPMENT MUSKE OON DEVELOPMENT MUSKEOON DEVLLOPMENT MUSKEOON DEVLLOPMENT MUSKECON OEVELOPMENT MUSKEOON DEVLLOPMENT MUSXEOON OEVEI OPMENT

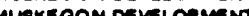
MuKE MLOKEOON DEVELORENT MUSKEOON OEVIOPMENT MUSKE GON OEVELOPMENT MUSKEOON OEVLLOPENT MUSKE GON DEVELOPMENT NOMECO ON 1 aAs CO

NOMECO OH 1 CAs CO NOMECO OK 2 ans

NOATHWE STEAN OLFIELO INVESTME NT OUFIELD INVESTMENTS OLFIELO INVESTMENTS OUFIELD INVESTMENTS shw, inC saw, inc anw. inc enw. INC. saw. inc IN Frelo on-UIN ON-UNE

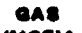

gavi atemae ren wel

onkr aremaec pen well (MCF). (mankels) (Mce). waren

$$
\begin{array}{r}
10 \\
10-20 \\
10 \\
21-24 \\
12-13 \\
24-27 \\
13-10 \\
13-17 \\
17-23 \\
11-13 \\
26-40 \\
10-10
\end{array}
$$

$32-34$

$32-34$
$01-62$

$0-20$

$11-16$

$21-28$

$18-10$

$13-10$

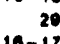

$16-17$
35

$30-31$

$30-30$

$24-26$

$0-10$

19

is

$0-10$

$0-11$
$0-11$

$0-10$

$0-10$

$0-10$
20

17

20

20
21
$0-1$

13

17
12
20

20
10

5

19

12

30
$0-6$
$0-0$

$0-9$
13

18-20

11
13

$17-24$

\begin{tabular}{|c|c|}
\hline $\begin{array}{l}2776600 \\
246661\end{array}$ & $\begin{array}{l}20400 \\
12300\end{array}$ \\
\hline 061040 & 144840 \\
\hline 230307 & 70416 \\
\hline 1070737 & 112201 \\
\hline 373416 & 46149 \\
\hline 303400 & 118730 \\
\hline 1233023 & 147700 \\
\hline 0S8423 & 123011 \\
\hline 1031024 & 330734 \\
\hline 254740 & 48604 \\
\hline eseses & 18762 \\
\hline 104279 & 09042 \\
\hline 2848010 & 303607 \\
\hline 201000 & 171212 \\
\hline 273304 & 107770 \\
\hline C41013 & 4205022 \\
\hline 412301 & 206331 \\
\hline 83s101 & 460736 \\
\hline 734163 & 60327 \\
\hline 601300 & 60154 \\
\hline 420170 & 244360 \\
\hline 36583i & 444740 \\
\hline 814017 & 74420 \\
\hline $21 \bullet 3414$ & 0 \\
\hline 2101607 & 0 \\
\hline 78804 & 205570 \\
\hline 203700 & 16131 \\
\hline 300303 & 103337 \\
\hline 201003 & 36400 \\
\hline 04004 & 47340 \\
\hline 208773 & Becor \\
\hline 00453 & 22408 \\
\hline 23202 & 10203 \\
\hline 206.33 & 18328 \\
\hline 6073 & 37300 \\
\hline 1110370 & 1040406 \\
\hline 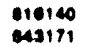 & $\begin{array}{l}130240 \\
120250\end{array}$ \\
\hline 740746 & O7840 \\
\hline 414113 & 301496 \\
\hline 873772 & 170038 \\
\hline 290396 & 00007 \\
\hline 424460 & 118184 \\
\hline 216305 & 11021 \\
\hline 462430 & s7est \\
\hline 004200 & 125041 \\
\hline 720301 & 282023 \\
\hline 42780 & $\$ 2012$ \\
\hline 1080100 & 144237 \\
\hline 203727 & 210200 \\
\hline 4as130 & 110000 \\
\hline 1088101 & 27700 \\
\hline 22017 & 54810 \\
\hline 242480 & 200704 \\
\hline 375715 & 183300 \\
\hline 476077 & 233050 \\
\hline 421712 & 210212 \\
\hline 233107 & 04000 \\
\hline 407060 & 301806 \\
\hline 040243 & 300320 \\
\hline 236397 & 200202 \\
\hline 472718 & 394060 \\
\hline 318170 & 04250 \\
\hline 711462 & 123020 \\
\hline 133480 & 337110 \\
\hline OA1462 & 200820 \\
\hline 860020 & 14794 \\
\hline 801003 & 104085 \\
\hline 124744 & 20010 \\
\hline 461107 & 01640 \\
\hline
\end{tabular}

$7-11$
$10-23$

10

24
26
-14

$14-10$
$20-22$

20-22

$18-16$

$18-10$
$0-0$
--0

0

182

ans maten

cresoje parrete

ires 420

2060105

2640

1890

$202 \quad 310$

$2130 \quad 260$

8104 041

$\begin{array}{ll}0717 & 081 \\ 4042 & 113\end{array}$

2315

$1736 \quad 103$

$3030 \quad 620$

2009

$2177 \quad 1308$

$\begin{array}{rr}2175 & 1252 \\ 4224 & 824\end{array}$

$\begin{array}{rr}1071 & 173 \\ 2209 & 1202\end{array}$

$\begin{array}{ll}2205 & 1202 \\ 171 & 1080\end{array}$

$1420 \quad 200$

$-024$

600
2570

$2310 \quad 602$

$1600 \quad 234$

1302

mons

2117

$607 \quad 3760$

$3401 \quad 670$

$\begin{array}{ll}5105 & 2804 \\ 1010 & 210\end{array}$

$1720 \quad 1423$

$2277 \quad 714$

$2724 \quad 750$

1068 359

$2570 \quad 302$

$\begin{array}{rl}3150 & 1240 \\ 713 & 1303\end{array}$

2017

1406

2031

2202

2440

24042

3100

1400
1050

422

2050

$3210 \quad 327$

780
3971

$2000 \quad 77$

3010

6eos

1001

867
000
01

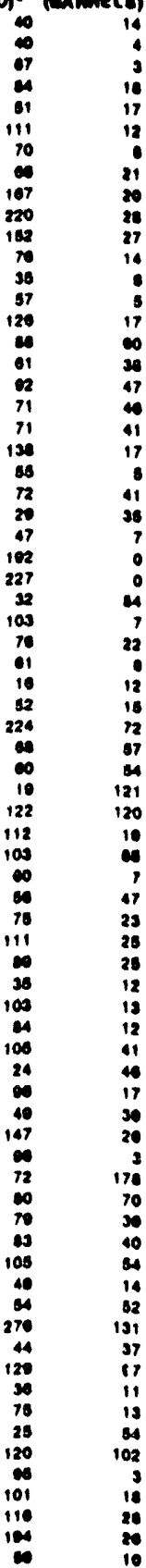

Table 1. MPSC Antrim Gas Well Database 1992. 


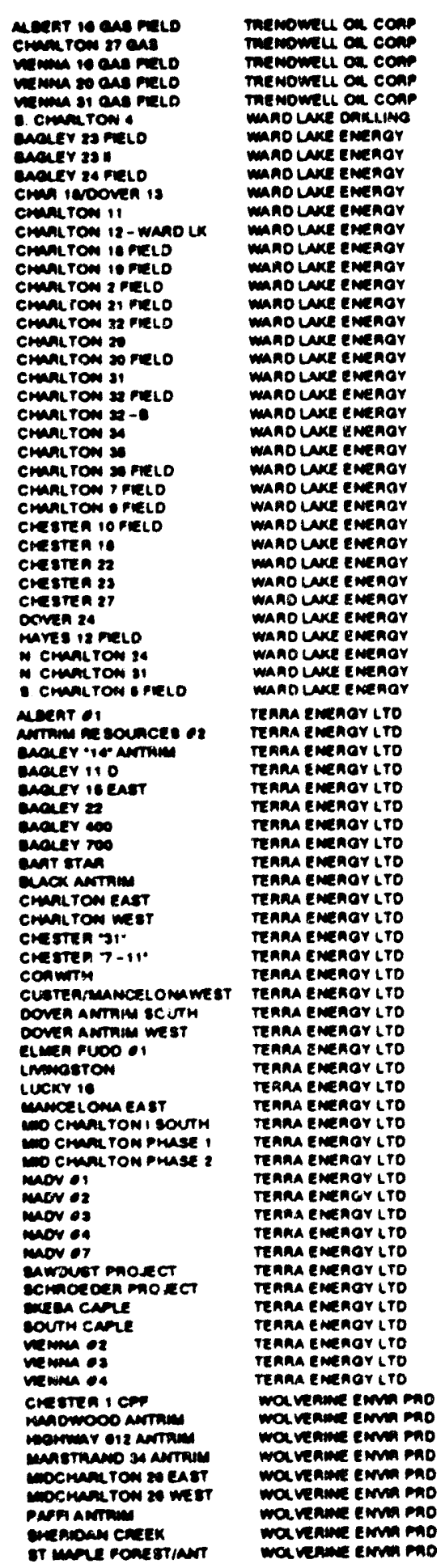

neport morenval ine ro i2m

rotus

\begin{tabular}{|c|c|c|c|c|c|c|}
\hline 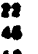 & $21-2$ & $\begin{array}{l}n \\
4 \\
13\end{array}$ & $\begin{array}{r}144910 \\
1242160 \\
\text { 1eres }\end{array}$ & teves & $\begin{array}{l}1744 \\
2200 \\
2000\end{array}$ & $\begin{array}{c}1010 \\
104 \\
0104\end{array}$ \\
\hline 12 & $0-12$ & $\begin{array}{l}13 \\
12\end{array}$ & $\begin{array}{l}\text { Teares } \\
\text { iossio }\end{array}$ & soorat & 1110 & 417 \\
\hline 27 & $20-27$ & 21 & 021000 & 2secen & 1040 & 749 \\
\hline 12 & 12 & 12 & c202430 & 4ente & 4720 & 2960 \\
\hline 16 & 14 & 14 & asent7 & 12220 & 1240 & 73 \\
\hline ? & $1-3$ & 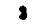 & 110064 & 13470 & sees & 673 \\
\hline 4 & 4 & 4 & 1437es & 8970 & 260 & 112 \\
\hline 10 & -16 & 10 & 442763 & 202772 & 2143 & 1480 \\
\hline 17 & 11 & 17 & $\$ 24004$ & 07273 & 2070 & 200 \\
\hline 10 & $10-18$ & 10 & 418600 & soren & 2001 & $\infty$ \\
\hline 4 & 0 & 0 & 0 & 0 & 0 & 0 \\
\hline ie & 10 & 10 & 481049 & 210706 & 107 & 24 \\
\hline 20 & 20 & 20 & 661700 & 200040 & 2716 & o7s \\
\hline 22 & 22 & $n$ & 446431 & 17 ear & 101 & 204 \\
\hline 17 & $0-17$ & $1 ?$ & 560243 & $\operatorname{coseces}$ & 2078 & 2710 \\
\hline$\bullet$ & $\bullet$ & - & 170001 & 26097 & 2472 & 369 \\
\hline 10 & 10 & 10 & 24412 & A44en & 2206 & 971 \\
\hline 14 & 14 & 14 & s7eices & cesces & 2442 & 202 \\
\hline 21 & 21 & 21 & reasese & (4496) & 3122 & 280 \\
\hline 2 & 2 & 2 & 107873 & 0214 & 4467 & 24 \\
\hline$\bullet$ & $0-0$ & - & 10010 & 10007 & 1092 & 200 \\
\hline 12 & 12 & 12 & 600600 & 6000 & 2008 & $\omega 1$ \\
\hline 22 & $0-22$ & 22 & osecess & $25502 s$ & 2173 & 1300 \\
\hline 22 & 22 & 22 & 403064 & 4sose & 1827 & 174 \\
\hline - & $\bullet$ & - & 200340 & cecess & 2101 & $\infty$ \\
\hline - & - & 4 & 248514 & 40786 & 2074 & son \\
\hline 82 & 62 & 62 & 1213000 & 190101 & 2040 & 234 \\
\hline 20 & 20 & 20 & 600707 & 201200 & 2392 & 230 \\
\hline 20 & 29 & 26 & osanzes & 285301 & 2128 & eAs \\
\hline - & - & 1 & 200014 & 317es & 2477 & 500 \\
\hline 2 & 3 & 2 & 100044 & 13844 & 2040 & 2330 \\
\hline 10 & 10 & 10 & 123500 & 122307 & 1040 & 1020 \\
\hline 26 & 25 & 28 & 747210 & 246000 & 2401 & 120 \\
\hline 14 & $0-14$ & 14 & 47000 & 20200 & 177 & 770 \\
\hline 12 & 12 & 12 & cerst1 & 77005 & 4043 & 6 \\
\hline 10 & $0-10$ & 10 & 21722 & 97212 & $\mathbf{2 4}$ & 1240 \\
\hline 10 & $11-19$ & is & Imane & 12411 & 1400 & 101 \\
\hline - & $\bullet$ & - & 373012 & 10072 & $\sin$ & 1300 \\
\hline 4 & $0-4$ & 4 & ineses & 28172 & 6612 & 1200 \\
\hline 1 & $0-1$ & 1 & 4386 & 3060 & 1600 & $\omega 7$ \\
\hline 1 & 1 & 1 & 87360 & 2108 & 4770 & 178 \\
\hline 22 & 22 & 22 & 281460 & $\cos 22$ & 1222 & 242 \\
\hline 13 & $0-12$ & 13 & 201400 & 243400 & $1 r r o$ & 2200 \\
\hline - & $0-0$ & $\bullet$ & 2002 & 12204 & 34 & 2040 \\
\hline $\mathbf{2 2}$ & 22 & 22 & 200400 & Miseo & 2370 & 2081 \\
\hline 30 & $24-20$ & $\mathbf{3 0}$ & 1261405 & 213040 & 4420 & 714 \\
\hline 44 & $\infty 0-44$ & 4 & 2147202 & 270146 & 4400 & 200 \\
\hline 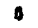 & - & 8 & 281710 & 44736 & 4166 & 140 \\
\hline 13 & 19 & 13 & 160402 & 149074 & 20030 & 020 \\
\hline 29 & $0-12$ & 12 & 30250 & 224022 & 268 & 240 \\
\hline 31 & s1 & 21 & 220002 & $14230 \mathrm{~s}$ & $\infty$ & 209 \\
\hline 21 & $10-21$ & 21 & 1143002 & 247120 & 6301 1 & 160 \\
\hline 10 & 10 & 10 & 31800 & a10300 & 1801 & 2184 \\
\hline 10 & $0-10$ & 10 & 24707 & 304042 & (1) & 0002 \\
\hline 4 & $0-3$ & J & 170 & 4670 & 200 & 1625 \\
\hline 17 & 17 & 17 & 204300 & 120003 & 1021 & 126 \\
\hline 10 & 10 & 10 & 115816 & 102037 & $\omega$ & 260 \\
\hline 10 & 10 & 10 & 111000 & 20004 & 2430 & $2 m$ \\
\hline 17 & $18-17$ & 17 & 1140730 & 174300 & 874 & ent \\
\hline 20 & $17-20$ & 20 & $12005 s 3$ & 506000 & 4378 & 180 \\
\hline ? & & 7 & $\infty 600$ & 11848 & 704 & 1416 \\
\hline - & - & - & 29784 & cesess & 313 & 118 \\
\hline 11 & 11 & 11 & 101752 & 107702 & $\pi 1$ & 817 \\
\hline 20 & 20 & 20 & 02300 & 122602 & 200 & (11 \\
\hline - & $7-6$ & - & 4ascest & or1014 & nanen & mor \\
\hline - & $0-6$ & - & 110960 & 2eanes & ceses & 400 \\
\hline 10 & 10 & 10 & sesile & 120002 & 227 & 1120 \\
\hline 11 & 11 & 11 & 20027 & 137210 & 1500 & 1000 \\
\hline 24 & 24 & 24 & 200000 & 146010 & 1041 & 820 \\
\hline 10 & $13-14$ & 14 & $\operatorname{sen} 100$ & C47310 & 2560 & 8731 \\
\hline 10 & 10 & 10 & 217241 & 160070 & 1811 & 1207 \\
\hline - & $0-0$ & - & 49170 & 240031 & 1201 & 407 \\
\hline 17 & 17 & 17 & coreit? & 100045 & 2001 & 6 \\
\hline 2 & $0-20$ & $x$ & $2107 e 4$ & 414600 & 1714 & 161 \\
\hline$\bullet$ & $0-0$ & $\bullet$ & 40141 & 100013 & 1409 & 2481 \\
\hline 20 & $10-20$ & 20 & anire & 247209 & 4728 & 2070 \\
\hline 10 & $19-10$ & 10 & 2ust7a & 27420 & 2023 & 162 \\
\hline 19 & $10-19$ & 13 & wreat & 2220 & 2018 & 220 \\
\hline 1 & $0-6$ & 1 & mat & 2160 & 376 & 2170 \\
\hline 6 & $0-1$ & 6 & ches & 12600 & 64 & 1200 \\
\hline 20 & .8 & $\mathbf{x}$ & 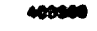 & 2000 & 1ent & 116 \\
\hline
\end{tabular}

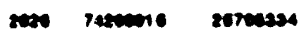

Table 1 (cont'd). MPSC Antrim Gas Well Database 1992. 


\section{DEVONIAN SHALE GAS OCCURRENCE, CHARACTERISTICS AND RESERVES}

\section{SHALE GAS OCCURRENCE AND CHARACTERISTICS}

\section{Antrim Shale Gas Generation}

The Antrim Shale is composed of black, calcareous gray, clastic gray and green shale lithologies. Gas occurs in the two black shale facies which are rich in organics. These gas producing horizons are in the Lower Antrim. The Lower Antrim is found at depths between 1,400 and 1,600 feet in Otsego County (Manger, 1991; Lang and Oliver, 1991). The two black shale facies are commonly known as the "Upper" and "Lower Black Shales". A "Middle" gray shale lies between the "Upper" and "Lower Black Shales". The "Lower Black Shale" facies overlies a "Lower" gray shale (Manger and Curtis, 1991) (Figure 13).

According to Manger and Curtis, the Antrim Shale gas is thermogenic in origin and was generated in place by thermal maturation of kerogen. The kerogen is believed to be of marine origin. Deposition occurred in a reducing environment. The Antrim Shale is believed to be the source and reservoir of the gas. Most Antrim wells are completed in the Upper Black Shale facies. Some wells are completed in just the Upper or Lower Black Shale while other wells are completed in both facies.

Antrim Shale gas production occurs from gas desorption of the organic rich black shale facies along natural fracture systems. Gas storage in the black shales occurs in matrix porosity and by adsorption. In one study, laboratory measurements on core samples from the Lower Antrim's Upper Black facies resulted in a calculated gas concentration of 12 $\mathrm{Bcf} / \mathrm{section}$ for a thickness of 80 feet. A calculated gas concentration of $4 \mathrm{Bcf} / \mathrm{section}$ was reported for core samples from the Lower Black Shale facies. A comparison of the measurements of the two intervals suggests that the Lower Black shale interval has a higher adsorbed gas capacity than the Upper Black. The total thickness of the Lower Black Shale in the area of study was approximately 20 feet (Lang anc Oliver, 1991). 


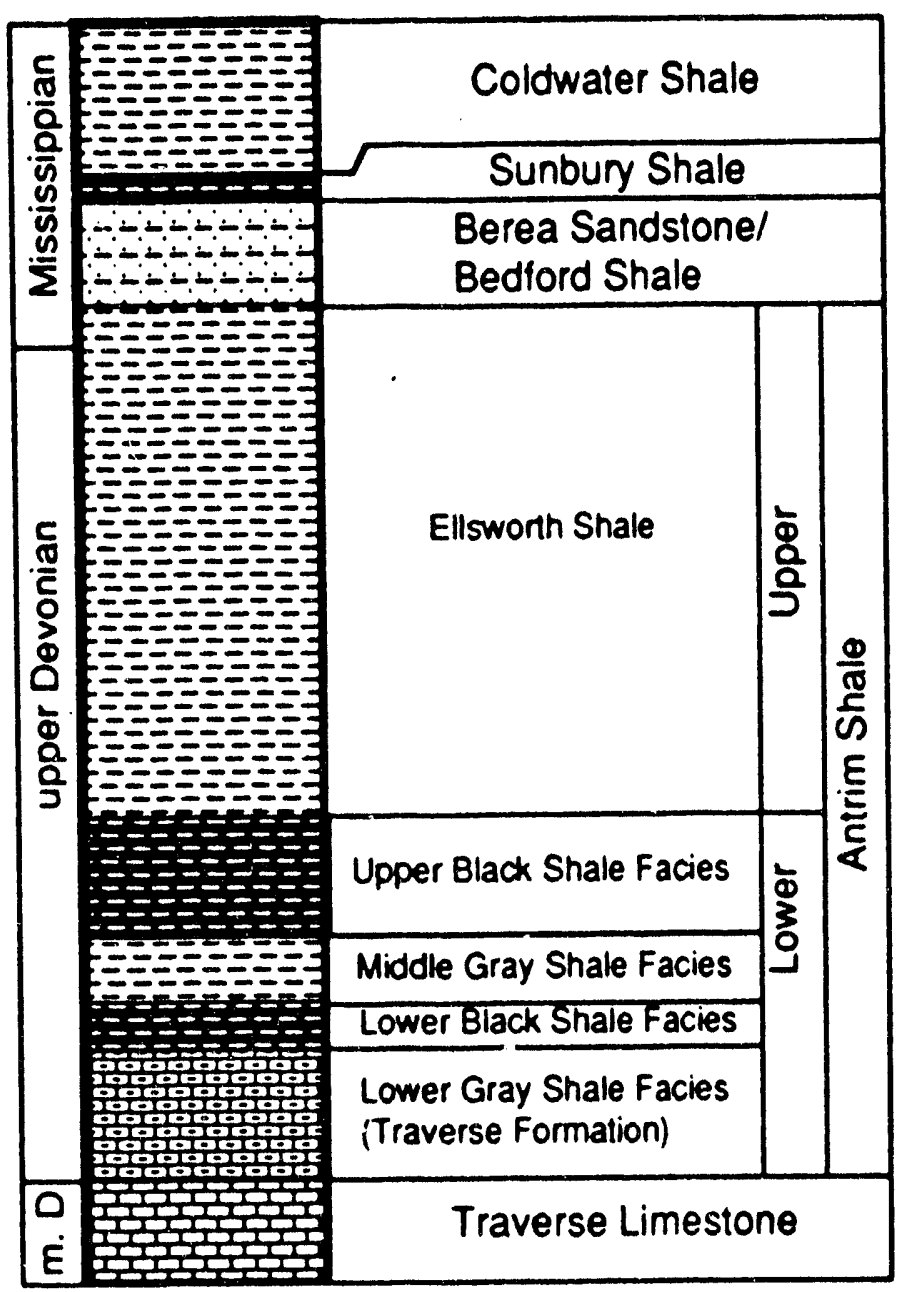

Figure 13. Antrim Shale Stratigraphy (from Manger and Curtis, 1991,GRI, Devonian Gas Shales Technology Review). 


\section{Porosity and Permeability of the Antrim Shale}

Matrix porosity measurements of core samples from the Upper Black, Middle Gray and Lower Black, ranged from 7 to $12 \%, 6$ to $10 \%$, and 6 to $14 \%$, respectively. The average matrix porosity was on the order of 10\% (Luffel, and others, 1991; Manger and Curtis, 1991).

Permeability of the Antrim Shale is along naturally occurring fractures. Dominant fracture orientations measured in one study trended northeast and southwest with some minor northwest to southeast orientations. The study also suggested that the number, intensity and the character of the fracture sets may be affected by mineralogy of the shale and structural features (Lang and Oliver, 1991). Permeability measurements of one well in Otsego County was 0.8 millidarcies (md) for gas and $20 \mathrm{md}$ for water (Smith, 1991). Additional permeability measurements of wells in the Antrim Shale averaged $0.2 \mathrm{md}$ and $0.6 \mathrm{md}$ for gas and water, respectively (Reeves, and others, 1992).

\section{Antrim Shale Gas and Water Production}

1990 Antrim gas production reported from about 1,400 wells totaled more than 100 MMscfd. Water production in 1990 totaled about 60,000 BWPD. In December, 1990, the average well produced $74 \mathrm{Mscfd}$ and $42 \mathrm{BWPD}$. The average depth of 814 conventional Antrim gas wells completed in 1990 was 1,672 feet. Initial potentials for the 814 wells averaged $45 \mathrm{Mcfd} / \mathrm{d}$ and $90 \mathrm{bwd}$. In 1990, 33 conventional brine disposal wells were drilled into the Dundee formation to an average depth of 2,480 feet. Also in 1990, 44 wells were drilled and permitted as combination production/disposal wells, i.e. "waterless" completions. These "waterless" completion wells were located in Antrim, Montmorency and Otsego Counties. Thirty-three of the wells are located in Otsego County. Thirty-five of the "waterless" completion wells drilled in 1990 have been reported to average initial potentials of $88 \mathrm{Mcfd} / \mathrm{d}$ (Roberts, 1991). 
Total 1992 Antrim Shale production from 2,626 wells was 74,209,916Mcf of gas and 25,795,334 bbl of water (MSPC Antrim Gas Well Database, 1993).

\section{SHALE GAS RESERVES}

\section{Antrim Shale-Estimated Sas in Place}

The Antrim Shale was reported to have a potential for up to $80 \mathrm{scf}$ of adsorbed gas per ton of shale and there is a reasonable expectation that there is potential for gas in the Antrim Shale outside of Otsego County (Manger and Curtis, 1991). The black shale facies is thought to cover an area of approximately 30,000 square miles. The estimated in-place gas resources of the Antrim Shale range from $16 \mathrm{bcf} / \mathrm{square}$ mile to over $35 \mathrm{bcf} / \mathrm{square}$ mile (Decker, 1992).

\section{HYDROGEOLOGIC SYSTEM}

\section{AQUIFERS}

The principal aquifers in the lower peninsula of Michigan are the glacial drift deposits and the consolidated Paleozoic bedrock formations.

\section{Glacial Drift Aquifer System}

Outwash, glaciofluvial, lacustrine sand and till deposits are the four types of glacial aquifers present over most of the basin. Most wells are less than 400 feet deep. Glacial deposits are up to 1,200 feet thick. 


\section{Bedrock Aquifers}

The principal freshwater bedrock aquifers are in descending order the Pennsylvanian Saginaw Formation, the Mississippian Marshall Formation, Silurian-Devonian rocks, Cambrian-Ordovician rocks, and Precambrian sandstone that outcrop near the surface. The Precambrian sandstone aquifers are confined to the Upper Peninsula and are not in the area of study. Principal aquifers of Michigan are shown in Figure 14. Table 2 shows common well depths and yields.

Transmissivity of the Saginaw Formation ranges from 130 to 3,300 square feet per day. Transmissivity values for the Marshall Formation range form 2,700 to 67,000 square feet/day.

\section{CONFINING FORMATIONS}

The general boundary for the separation of the freshwater aquifers and the brine containing formations is the Coldwater Shale. The Marshall Formation overlies the Coldwater and except for the shallow outcrops of older formations which supply freshwater near the perimeter of the Michigan Basin, is the basal freshwater aquifer.

Several shale formations, such as the Sunbury, the Bedford, the Ellsworth and the Coldwater confine the lower Antrim Shale water and gas. The Dundee Limestone is confined by the Bell Shale and the Traverse Group.

\section{GROUNDWATER QUALITY}

Generally, freshwater is obtained from the glacial deposits and shallow Paleozoic limestone and sandstone formations that outcrop at the surface. Total dissolved solids (TDS) concentration of glacial aquifers ranges from 100 to $500 \mathrm{mg} / \mathrm{L}$. Average TDS concentration of the Saginaw Formation is $1,600 \mathrm{mg} / \mathrm{L}$. In some areas, TOS concentrations for the Sagninaw Formation can range from 300 to $800 \mathrm{mg} / \mathrm{L}$. The Marshall Formation 

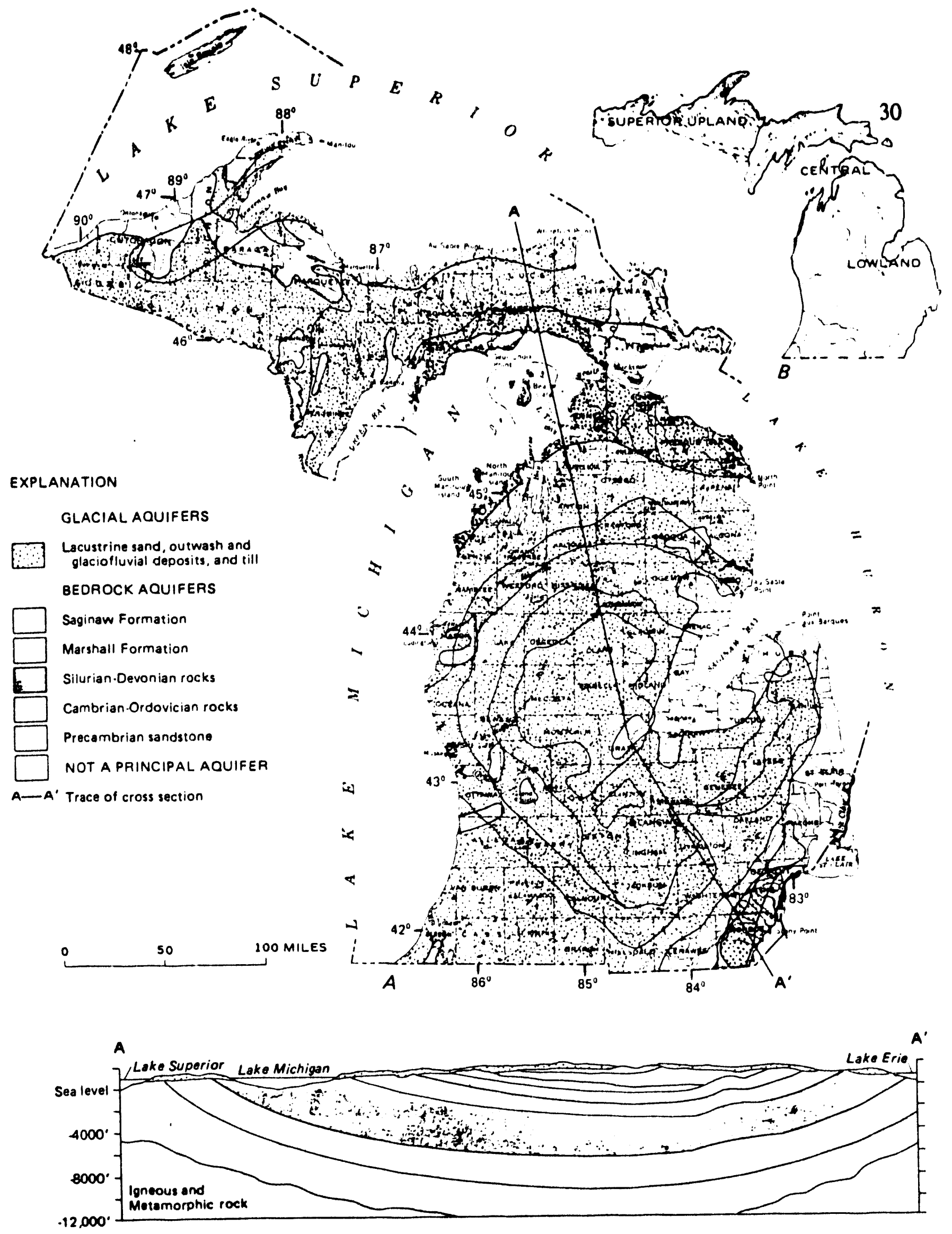

Figure 14. Principal Aquifers in Michigan (from USGS Water Supply Professional Paper 2275, 1985). 
IFt = feet; gal/min = gallons per minute. Sources: Reports of the U. S. Geolocical Survey and Michizan Department of Natural Resources, Geological Survey Division)

\begin{tabular}{|c|c|c|c|c|c|}
\hline \multirow{3}{*}{ Aquiler name and description } & \multicolumn{4}{|c|}{ Woll characterlstics } & \multirow{3}{*}{ Remarks } \\
\hline & \multicolumn{2}{|c|}{ Depth (ft) } & \multicolumn{2}{|c|}{ Yleld (gal/min) } & \\
\hline & $\begin{array}{c}\text { Common } \\
\text { range }\end{array}$ & $\begin{array}{c}\text { May } \\
\text { exceed }\end{array}$ & $\begin{array}{c}\text { Common } \\
\text { range }\end{array}$ & $\begin{array}{c}\text { May } \\
\text { exceod }\end{array}$ & \\
\hline $\begin{array}{l}\text { Glacial aquifers: } \\
\text { Outwash and glaciofluvial deposits: } \\
\text { Sand and gravel, contains silt } \\
\text { and clay in places. } \\
\text { Mostly unconfined. }\end{array}$ & $25-200$ & 400 & $1-1,000$ & 2,000 & $\begin{array}{l}\text { Water generally hard; large } \\
\text { iron concentrations common; } \\
\text { deep wells may produce } \\
\text { salty water in places. }\end{array}$ \\
\hline $\begin{array}{l}\text { Lacustrine sand: Sand, some gravel, } \\
\text { and interbedded silt and clay. } \\
\text { Mostly unconfined. }\end{array}$ & $25-100$ & 200 & $80-500$ & 500 & $\begin{array}{l}\text { Used for domestic supplies in } \\
\text { Saginaw Bay and Detroit areas; } \\
\text { is salty in places at depth. }\end{array}$ \\
\hline $\begin{array}{l}\text { Till: Intermixed clay, silt, sand, } \\
\text { gravel and boulders; sand and gravel } \\
\text { lenses abundant in some areas. } \\
\text { Confined and unconfined. }\end{array}$ & $25-200$ & 400 & $s-200$ & 200 & $\begin{array}{l}\text { Primary source of domestic } \\
\text { supply in western Upper } \\
\text { Peninsula. }\end{array}$ \\
\hline $\begin{array}{l}\text { Bedrock aquifers: } \\
\text { Saginaw Formation: Sandstone, } \\
\text { silistone, some shale, limestone, } \\
\text { and coal. Mostly confined. }\end{array}$ & $25-300$ & 500 & $100-300$ & 1,000 & $\begin{array}{l}\text { One of Michigan's most important } \\
\text { bedrock aquifers: water generally hard; } \\
\text { salty in places at depth. }\end{array}$ \\
\hline $\begin{array}{l}\text { Marshall Formation: Sandstone } \\
\text { and siltstone. Mostly confined } \\
\text { or semiconfined, unconfined at } \\
\text { places. }\end{array}$ & $25-200$ & 400 & $100-500$ & 1,500 & $\begin{array}{l}\text { Another of Michigan's important } \\
\text { bedrock aquifers; salty in } \\
\text { places and at depth. }\end{array}$ \\
\hline $\begin{array}{l}\text { Silurian-Devonian rocks: } \\
\text { Limestone and dolomite; some } \\
\text { shale and sandstone. Mostly } \\
\text { confined. }\end{array}$ & $25-150$ & 200 & $10-300$ & 300 & $\begin{array}{l}\text { Important aquifer in parts of } \\
\text { eastern Upper Peninsula; } \\
\text { water commonly hard. }\end{array}$ \\
\hline $\begin{array}{l}\text { Cambrian-Ordovician rocks: } \\
\text { Sandstone, limestone, and } \\
\text { dolomite. Mostly confined. }\end{array}$ & $25-150$ & 200 & $10-100$ & 500 & $\begin{array}{l}\text { Important aquifer in eastern } \\
\text { Upper Peninsula; water } \\
\text { commonly very hard; salty } \\
\text { in places and at depth. }\end{array}$ \\
\hline $\begin{array}{l}\text { Precambrian sandstone: Sandstone } \\
\text { interbedded with siltstone. } \\
\text { Mostly confined. }\end{array}$ & $25-400$ & 500 & $5-50$ & 100 & $\begin{array}{l}\text { Important aquifer in western } \\
\text { Upper Peninsula; salty in } \\
\text { places. }\end{array}$ \\
\hline
\end{tabular}

Table 2. Aquifer and Well Characteristics in Michigan (from USGS Water Supply Professional Paper 2275, 1985). 
usually has a TDS concentration of less than $500 \mathrm{mg} / \mathrm{L}$. Silurian-Devonian aquifers generally have a TDS concentration of less than $500 \mathrm{mg} / \mathrm{L}$. Cambrian-Ordovician aquifers have a TDS concentration range of about 150 to $2,000 \mathrm{mg} / \mathrm{L}$. Groundwater quality deteriorates with depth and towards the center of the Michigan basin. Deeply buried aquifers contain saline or brine waters (USGS, Water-Supply Professional Paper 2275, 1985).

\section{UNDERGROUND INJECTION}

\section{Formations Accepting Disposal of Produced Water}

Many formations, primarily dolomites and sandstones, are used for injection of produced waters. Most shales and limestone sequences that are continuous and not fractured are good confining units. Records were reviewed for current injection zones for produced water from the Antrim Shale. Current Antrim Shale "Waterless Completions" Class II production/disposal wells are permitted to inject into the Middle Devonian Dundee Limestone. The Dundee has very good porosity and permeability where it is dolomitized (Western Michigan University, 1981). Permeabilities measured up to $650 \mathrm{md}$. The Dundee is know for a pronounced hydraulic low in the central area of the Lower Peninsula which is believed to be related to hydrocarbon production (Vugrinovich, 1986).

A potential injection zone for deep gas plays with significant water production is the Cambrian Mt. Simon Sandstone. The Mt. Simon Sandstone is believed to have the potential to accept a large quantity of fluids for disposal. Porosity ranges from 4 to 20 percent. Average permeability measured was $32 \mathrm{md}$. However the Mt. Simon is used for water supply in southwestern Michigan and in some areas of the basin, the cost of deep injection may not be economical (Briggs, 1968). 


\section{SUMMARY}

The Michigan Basin is an interior cratonic basin with a Paleozoic sedimentary section up to 16,000 feet in total thickness. Quaternary glacial drift deposits extend across most of the basin and overlie Jurassic and Paleozoic bedrock formations.

Pennsylvanian coal seams of the Saginaw Formation are generally at shallow depths ( $<1000$ feet), laterally discontinuous and were not reported to be a potential major resource for coal-bed methane gas. Oil and gas is produced from Mississippian to Ordovician-age formations. The majority of the fields produce oil and gas along with water and were not considered for this report. A more localized study of individual wells which produce gas and significant quantities of water may reveal potential application of Jack Mclntyre's gas recovery/water disposal process.

The Devonian Antrim Shale is a major natural gas reservoir which produces significant quantities of gas and water. To date, over 2,700 wells have been completed in the Antrim Shale. Antrim Shale gas and water annual production for 1992 totaled $74,209,916 \mathrm{Mcf}$ of gas and $25,795,334 \mathrm{bbl}$ of water, respectively, for 2,626 on-line wells in 156 fields. The Middle Devonian Dundee Limestone is a major injection zone which is used for disposal of produced waters from the Antrim Shale. "Waterless Completion" wells are producing Antrim Shale gas and simultaneously disposing of water into the Dundee Limestone.

Jack W. McIntyre's patented process for gas recovery and water disposal has potential application for dewatering of the Antrim Shale into the Dundee Limestone in the Michigan Basin. "Waterless" completion wells are currently in use in the Antrim Shale gas reservoir and the Dundee Limestone injection zone. 


\section{ACKNOWLEDGEMENT}

The authors express thanks to the United States Department of Energy (DOE) for funding this work. The grant was awarded to Jack W. McIntyre under DOE Contract No. DEJ-FG46-92R699202. Mr. McIntyre contracted Geraghty \& Miller to perform this research. Greatly appreciated is the assistance and materials provided by the staffs of the Gas Research Institute, Michigan Public Service Commission, Michigan Department of Natural Resources, United States Geological Survey in Denver, Colorado and Lansing, MI, and the Petroleum Department of the Midland,Texas County Library. Special thanks go to Robert Miller, G\&M project manager, and Hugh Robotham, G\&M hydrologist, for technical review, and Sandra Elliott for editorial review. Thanks to Carol Ballard, Pam Covington and Rose Shive for word processing and reproduction.

\section{DISCLAIMER}

Mention of specific processes, brand names or models of equipment is for information only and does not imply endorsement of any particular process or brand. 


\section{REFERENCES}

1991 Annual Well Status Summary (AWSUM):1993, Michigan Department of Natural Resources, Geological Survey Division Open File Report OFR 93-01, 1716 p.

Averitt, Paul, Coal Resources of the United States, January 1, 1974: 1975, U.S. Geological Survey Bulletin 1412, 131 p., figs., tbls.

Briggs, L.I., 1968, Geology of Subsurface Waste Disposal in the Michigan Basin: in J. E. Galiey (ed.), Subsurface Disposal in Geologic Basini - A Study of Reservoir Strata, American Association of Petroleum Geologists Memoir 10, pp 128-153.

Catacosinos, Paul A., and Harrison, William B., III, and Daniels, Paul A., Jr., 1990, Structure, Stratigraphy, and Petroleum Geology of the Michigan Basin, Interior Cratonic Basins, American Association of Petroleum Geologists Memoir 51, pp 561601.

Cohee, G.V., Burns, R.N., Brown, Andrew, Brant, R.A., and Wright, Dorothy, 1950, Coal Resources of Michigan, United States Geological Survey Circular 77, $56 \mathrm{p}$.

Decker, David A., 1991, Log-based Gas Content and Resource Estimates for the Antrim Shale, Michigan Basin, Gas Shales Technology Review, Vol. 8, No. 1, December, 1992, pp 1-10.

Ells, G.D., 1979, Stratigraphic Cross Sections Extending from Devonian Antrim Shale to Mississippian Sunbury Shale in the Michigan Basin, Report of Investigation 22, Michigan Department of Natural Resources, Geological Survey Division , p.186, 21 plates.

Fowler, J.H., and Kuenzi, W.D., 1978, Keweenawan Turbidites in Michigan (deep borehole red beds): A Foundered Basin Sequence developed During Evolution of a ProtoOceanic Rift System, Joumal of Geophysical Research, V.83, p. 5833-5843.

Hinze, W.J., and D.W. Merritt, 1969, Basement Rocks of the Southern Peninsula of Michigan, in H.B. Stonehouse (ed.), Studies of the Precambrian of the Michigan Basin, Michigan Basin Geological Society Annual Field Excursion, p. 28-59.

Hinze, W.J., R.L. Kellogg, and N.W. O'Hara, 1975, Geophysical Studies of Basement Geology of Southern Peninsula of Michigan, American Association of Petroleum Geologists Bulletin, V.59, p. 1562-1584.

Kalliokoski, J., and Welch, E.J., 1977, Magnitude and Quality of Michigan's Coal Reserves, Michigan Technological University, Department of Geology and Geological Engineering, U.S. Bureau of Mines Open-File Report OFR-102-76, 33 p., 8 map sheets. 
Kelley, R.W., 1968, Bedrock of Michigan, Small Scale Map 2, Michigan Department of Conservation, Geologic Survey, 1 map.

Lang, Karl R., and Oliver, Stephen J.P., 1991, Reservoir Characterization and Performance in the Antrim Shale, Devonian Gas Shales Technology Review, July 1991, Vol 7, No. 2, pp 34-49.

Lilienthal, R.T., 1978, Stratigraphic Cross-Sections of the Michigan Basin, Michigan Geological Survey Division, Report Investigation 19, 36 p., figs., pls.

Luffel, D.L.,Olszewski, A.J., Raymer, L., Formation Evaluation Technology for Production Enhancement, Annual Technical Report (October 1989-October 1990), GRI 5086213-1390, January 1991, pp 41-98.

Manger, Katherine C., and Curtis, Dr. John B., 1991, Geologic Influences on Location and Production of Antrim Shale gas, Devonian Gas Shales Technology Review, July 1991, Vol. 7, No. 2, pp 5-16.

Michigan Department of Natural Resources, 1977, Stratigraphic Succession in Michigan, Chart 1, Michigan Department of Natural Resources, Geological Survey Division, 1 fig.

Michigan Oil \& Gas Fields, 1985-1986: 1993, Michigan Department of Natural Resources, Geological Survey Division Open File Report OFR 89-01, 310 p.

MPSC Antrim Gas Well Database, Report Interval (Jan. 1992-Dec. 1992), Report Date: Mar. 10, 1993, Michigan Public Service Commission, Lansing, MI, 68 p.

Newcombe, R.B., 1933, Oil and Gas Fields of Michigan, Michigan Geological Survey Publication 38 (Geological Series 32), 293 p.

Reeves, Scott R., Morrison, William K., and Hill, David G., 1992, Improved Production Practices for the Antrim Shale, Gas Shales Technology Review, Vol. 8, M!o. 1, December, 1992, pp. 11-19.

Roberts, Peter A., 1991, 1990 Antrim Shale Drilling and Production Statistics, Devonian Gas Shales Technology Review, July 1991, Vol. 7, No. 2, pp 50-55.

Smith, Dr. Michael B., 1991, Stimulation Effectiveness in the Antrim Shale: Devonian Gas Shales Technology Review, July 1991, Vol. 7, No. 2, pp 17-33

United State Geological Survey, 1985, National Water Summary 1984, Hydrologic Events, Selected Water-Quality Trends, and Ground-Water Resources, U.S. Geological Survey Water Supply Paper 2275, 467 p., figs, tbls.

Vugrinovich, Raymond, 1986, Patterns of Regional Subsurface Fluid Movement in the 
Michigan Basin: Michigan Department of Natural Resources Gerlogical Survey Division Open File Report OFR 86-6, 27 p.

Weist, William G., Jr., 1978, Summary Appraisals of the Nation's Ground-Water Resources-- Great Lakes Region, U. S. Geological Survey Professional Paper 813-J, 30 p.

Western Michigan University, 1981, Hydrogeology for Underground Injection Control in Michigan, Part 1, Kalamazoo, Western Michigan University, 758 p. 

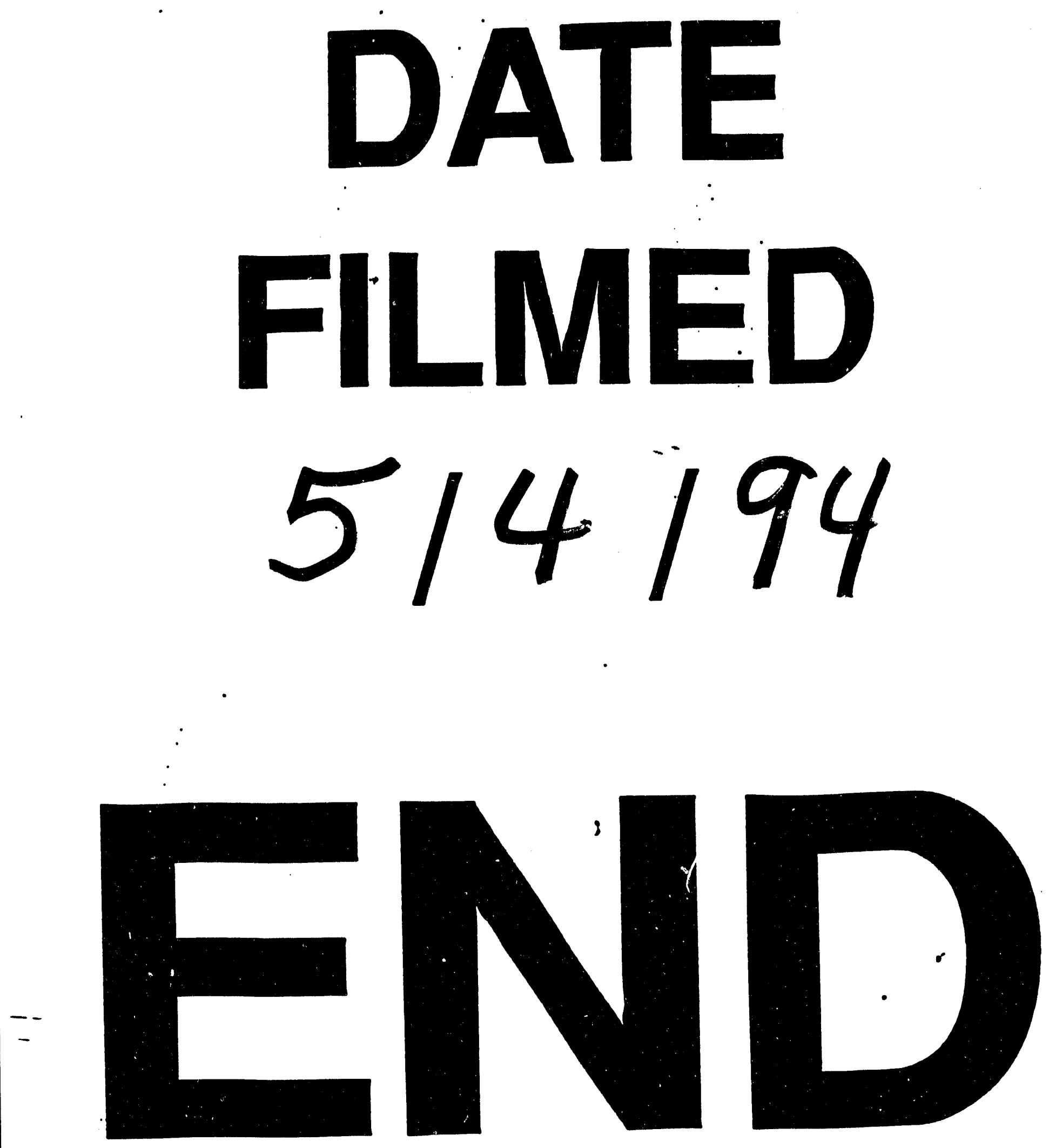
